\title{
JOHANN WOLFGANG GOETHE-UNIVERSITÄT FRANKFURT AM MAIN
}

FACHBEREICH WIRTSCHAFTSWISSENSCHAFTEN

Reinhard H. Schmidt / Marcel Tyrell

What constitutes a financial system in general and the German financial system in particular?

No. 111

July 2003

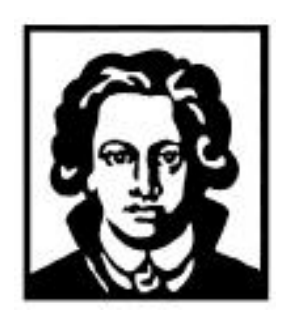

WORKING PAPER SERIES: FINANCE \& ACCOUNTING 
Reinhard H. Schmidt and Marcel Tyrell

\author{
What constitutes a financial system in general \\ and the German financial system in particular?
}

No. 111

July 2003

ISSN 1434-3401

Forthcoming as Chapter 2 of the book "The German Financial System", edited by Jan P. Krahnen and Reinhard H. Schmidt, to be published by Oxford University Press, London (2003)

WORKING PAPER SERIES FINANCE AND ACCOUNTING ARE INTENDED TO MAKE RESEARCH FINDINGS AVAILABLE TO OTHER RESEARCHERS IN PRELIMINARY FORM, TO ENCOURAGE DISCUSSION AND SUGGESTIONS FOR REVISION BEFORE FINAL PUBLICATION. OPINIONS ARE SOLELY HOSE OF THE AUTHORS. 


\begin{abstract}
This paper is one of the two introductory chapters of the book "The German Financial System". It first discusses two issues that have a general bearing on the entire book, and then provides a broad overview of the German financial system.

The first general issue is that of clarifying what we mean by the key term "financial system" and, based on this definition, of showing why the financial system of a country is important and what it might be important for. Obviously, a definition of its subject matter and an explanation of its importance are required at the outset of any book. As we will explain in Section II, we use the term "financial system" in a broad sense which sets it clearly apart from the narrower concept of the "financial sector". The second general issue is that of how financial systems are described and analysed. Obviously, the definition of the object of analysis and the method by which the object is to be analysed are closely related to one another.

The remainder of the paper provides a general overview of the German financial system. In addition, it is intended to provide a first indication of how the elements of the German financial system are related to each other, and thus to support our claim from Section II that there is indeed some merit in emphasising the systemic features of financial systems in general and of the German financial system in particular.

The chapter concludes by briefly comparing the general characteristics of the German financial system with those of the financial systems of other advanced industrial countries, and taking a brief look at recent developments which might undermine the "systemic" character of the German financial system.
\end{abstract}




\section{Table of Contents}

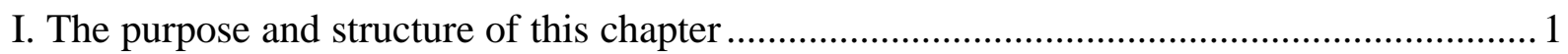

II. The meaning of the term "financial system" and the importance of financial systems .........2

1. Defining terms and topics: "financial sector" versus "financial system" ..........................2

2. The importance of having a good financial system.................................................. 4

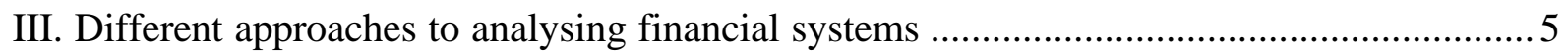

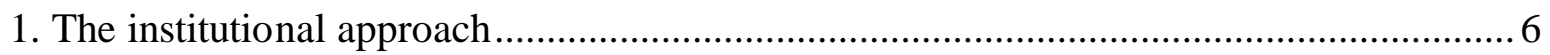

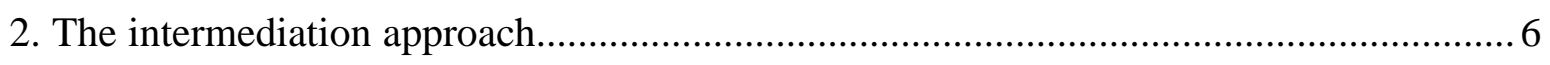

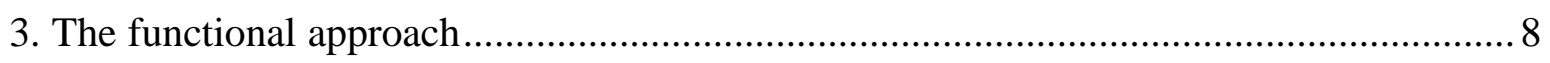

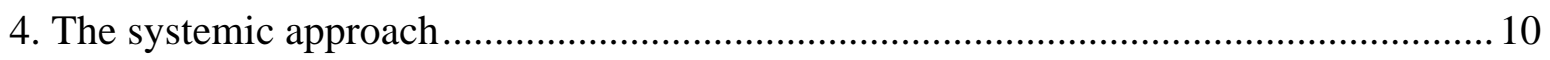

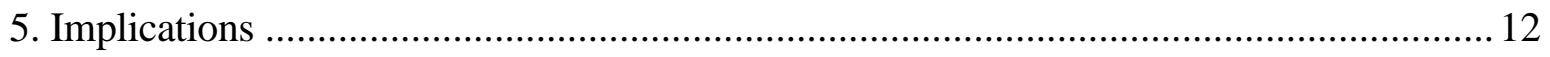

IV. The German financial system: An overview of its characteristic features ....................... 13

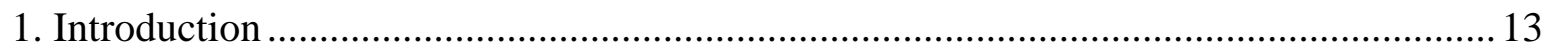

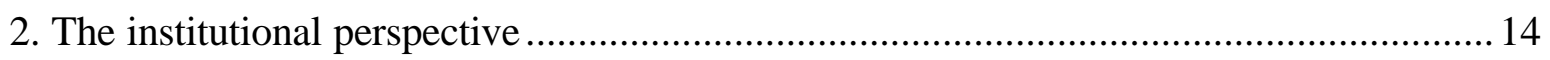

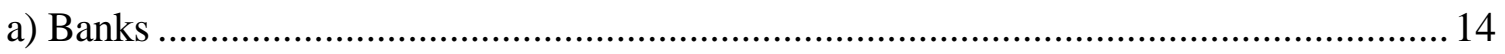

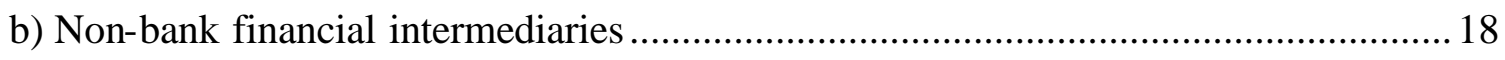

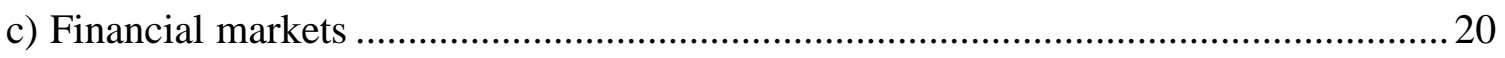

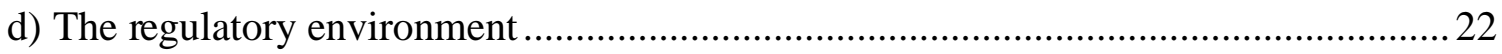

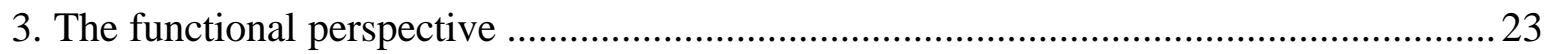

a) Intermediation and the distribution of roles in the financial sector...........................2. 24

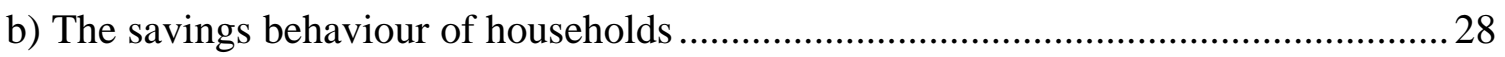

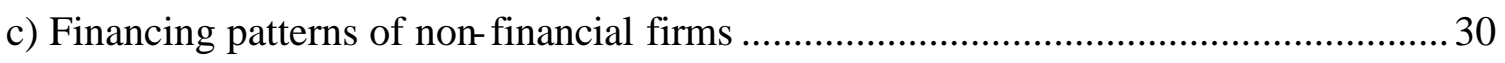

d) Risk-sharing, risk allocation, and the German pension system ................................ 33

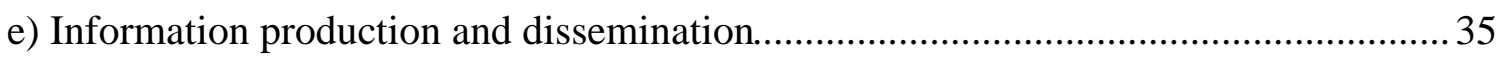

f) The control of capital: Corporate governance in Germany ....................................... 36

4. The systemic perspective: Complementarity and consistency ..................................... 40

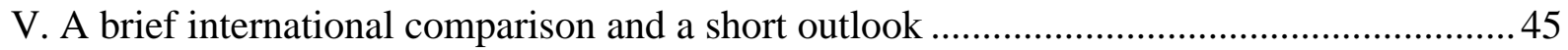

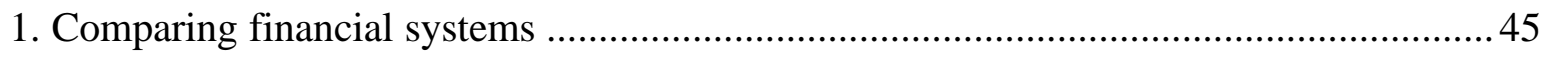

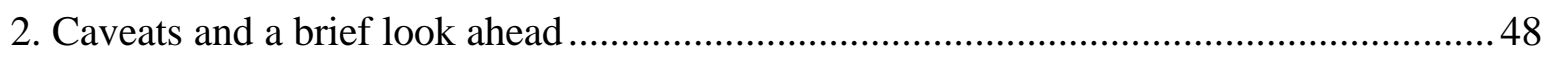

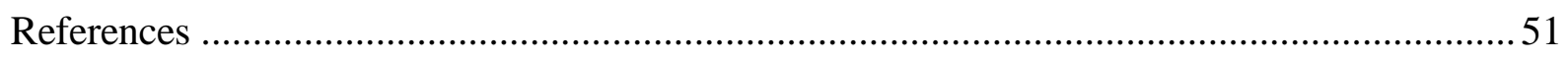




\section{The purpose and structure of this chapter}

This chapter first discusses two issues that have a general bearing on the entire book, and then provides a broad overview of the German financial system. The first general issue is that of clarifying what we mean by the key term "financial system" and, based on this definition, of showing why the financial system of a country is important and what it might be important for. Obviously, a definition of its subject matter and an explanation of its importance are required at the outset of any book. But it is all the more important in our case because the term "financial system" is used in a number of very different ways, both in the academic literature and in non-academic discourse, and because the importance of the financial system is not generally acknowledged. As we will explain in Section II, we use the term "financial system" in a broad sense which sets it clearly apart from the narrower concept of the "financial sector".

The second general issue, which we will take up in Section III, involves a discussion of how financial systems are described and analysed. This is a necessary step too, since there is no standard way of doing it. Obviously, the definition of the object of analysis and the method by which the object is to be analysed are closely related to one another. The overall structure of the present book reflects our broad definition of the term "financial system": it deals not only with the German financial sector, but also with financial aspects of what happens in the real sectors of the German economy. As we will argue, we consider that the most useful approach to describing and analysing financial systems is one which emphasises the ways in which the various elements of a financial system are related to each other, and in which they interact. In other words, we wish to underscore the fact that a financial system really is a system, and to explain why this is so.

In Section IV we will then provide a first general overview of the German financial system. In addition to putting the following chapters into perspective, this overview serves two purposes. It is intended to provide a first indication of how the elements of the German financial system are related to each other, and thus to support our claim that there is indeed some merit in emphasising the systemic features of financial systems in general and of the German financial system in particular; and it is intended to at least partially compensate for the inevitable gaps in the material presented in the remainder of the book. The chapter concludes by briefly comparing the general characteristics of the German financial system with those of the financial systems of other advanced industrial countries, and taking a brief look at recent developments which, as will be argued at greater length in the concluding chapter of the book, might 
undermine the "systemic" character of the German financial system, a crucial aspect which is emphasised in Section IV.4.

\section{The meaning of the term "financial system" and the importance of financial systems}

\section{Defining terms and topics: "financial sector" versus "financial system"}

What is a financial system, and what does the term "financial system" properly refer to? The answer to these questions is not obvious, as one can easily see if one imagines the situation of a young World Bank economist who is instructed by her superiors to fly to some far-away country and come back with an overview of the "financial system" of that country. What would she look at and what should she look at? What would those who sent her on the mission be interested in knowing?

She would certainly come back with information concerning the central bank and the monetary system of the country, its banks, and its stock market, if there is one. But this information may not be all that her superiors want to know. A policy-relevant analysis should put first thing first. At least at a conceptual level, the analysis of any financial system should start with people and their business endeavours; it should examine their financial needs and their demand for financial services, and it should identify the ways in which these needs are satisfied and their demand is met. Accordingly, the underlying questions are:

- How do people accumulate wealth and transfer income over time? Which options are available and how are they used?

- How do businesses obtain financing if they, or their owners or managers, have attractive investment opportunities for which their own funds would not be sufficient?

- How do people cope with risks?

Addressing these questions raises others, some of which may be more familiar: Are there institutions in that country which meet the demand for savings opportunities, credit facilities and risk-management or insurance services? And if they exist, what is the nature of those institutions, how do they function, who owns and governs them, how do they operate, and how are they designed and regulated? And most importantly, what role do those institutions play in helping real people to solve their financial problems? How important is external financing in comparison to internal financing? How important are real savings or real investment, as means of storing and ransferring wealth over time, in comparison to financial 
savings? And how important is formal insurance relative to other methods of risk mitigation, i.e., those which involve measures confined solely to the real sectors of the economy? How important are formal, i.e. regulated and supervised, financial institutions and organised markets in comparison to informal financial relationships, such as those that may exist between friends and family members? Are the financial institutions and the organised markets "good" according to some suitable standard? And is the legal and regulatory system conducive to the provision of financial services and the establishment of financial institutions and their proper functioning?

These questions are equally important for all countries, irrespective of whether one looks at Indonesia, Poland or Germany. As the young World Bank economist will hopefully have come to realise after a few days, the formal financial institutions may not be the most important part of the financial system of any of these countries. These considerations motivate our distinction between two concepts and their definitions.

The narrow concept is that of the financial sector. We define the financial sector as that part - or sector - of an economy which offers and provides financial services to the other sectors of the economy. It consists of the central bank, other banks, non-bank financial institutions, organised financial markets and the relevant regulatory and supervisory institutions.

The broader concept is that of the financial system. It can be defined in general terms as the interaction between the supply of and the demand for the provision of capital and other finance-related services.

In addition to the supply side, i.e. the financial sector and its activities, the concept of the financial system also includes the demand side and thus the economic units which may demand financial services. The demand for these services comes from many economic units, but most importantly from households which accumulate wealth or simply carry income over from one time period to the next, and from firms which need capital for investing.

The widening of the focus is more than a change of definition, since the concept of the financial system also includes units in the non-financial sector in so far as they do not demand, or do not succeed in obtaining, services from the formal financial sector. Indeed, if we wish to understand the financial system of a country, we must also indicate the extent to which, and the forms in which, households and other surplus units undertake real investment merely in order to accumulate and transfer assets; how firms and other deficit units obtain financing directly from households and other surplus units or engage in self-financing; and how house- 
holds and firms protect themselves against risks. The state is also a part of the financial system, not only because it too supplies and demands financial services, but also because it serves as the organiser and regulator of the financial sector.

There is a second dimension in which the concept of the financial system is broader than that of the financial sector. Financial flows are mirrored in flows of information and flows of potential and actual influence. From the perspective of new institutional economics, there are obvious reasons why this is so, and it is also obvious that financial flows, information flows and flows of influence are interdependent: each of the three types of relationship plays a key role in determining the nature of the other two types. Actual and potential flows of information and influence constitute the essence of "the corporate governance system". As finance without governance would scarcely be possible, the corporate governance system is therefore an integral part of the financial system of any country. ${ }^{1}$

\section{The importance of having a good financial system}

For a long time it has been common knowledge among economists that a well-functioning financial system is important for welfare and growth. Hilferding, for example, emphasised the role of the German banks in supporting the belated growth of industry in Germany. Schumpeter's view of the banker as the partner and supporter of the entrepreneur is well known, as is Gerschenkron's historic account of this role. ${ }^{2}$ Practitioners in banking and business as well as politicians who are active in this area will typically share the view that "finance matters".

The conventional view of the financial system as a factor contributing to growth lost its prominence in academic circles at the time when the neoclassical theory of economic growth gained general acceptance, as the analytical structure of this theory does not accommodate banks or the financial sector in general. Moreover, while some economists continued to

\footnotetext{
${ }^{1}$ Many authors make a distinction between the narrow and the broad concept which largely corresponds to our distinction between the financial sector and the financial system. But their terminology does not always reflect this distinction; the term "financial system" is often used to denote merely the financial sector.

2 See Hilferding (1910), Schumpeter (1911) and Gerschenkron (1962). The case studies in McKinnon (1973) provided some early evidence that finance matter. However, the importance of German banks in the late $19^{\text {th }}$ and early $20^{\text {th }}$ centuries is questioned in more recent work by Fohlin (2000), Verdier (1999) and Rajan/Zingales (2001).
} 
consider financial development as an engine of growth, others claimed that it was not a cause but rather a consequence and a symptom of real economic development. ${ }^{3}$

The discussion about the role and importance of financial systems was revived around 1990 . The World Development Report of 1989, which was dedicated to this topic, provided the first econometric evidence that finance matters for growth and development; and it also suggested a causal link running from finance to growth. This strand of research culminated in the work of King and Levine. As the title of one of their influential papers indicates, they claim that "Schumpeter might be right" (King/Levine, 1993). More recent work, which is summarised in Levine (1997) and Winkler (2001), points in the same direction.

If one looks at this literature in detail one can easily recognise that, in its search for academic rigour, it does not in fact refer to the entire financial system in the broad sense introduced above, but more narrowly to the financial sector. However, the finding can easily be generalised using such arguments as those put forward in the work on "law and finance" by La Porta et al. ${ }^{4}$ Thus, at least at the current state of the debate, one can safely conclude that a good financial system seems to be conducive to economic welfare and growth and that therefore the topic of this book is indeed an important one. But this then raises the question of standards of assessment. We will address this question in the following section.

\section{Different approaches to analysing financial systems}

As there are many contexts in which the financial system is considered to be relevant, it is not surprising that there are also many different ways in which financial systems are described and analysed in the literature. Each of them reflects not only a different focus, but also a different concept of what is, and what is not, part of the financial system. However, there does not seem to exist a common view of how one should describe financial systems. ${ }^{5}$

In what follows, we shall briefly characterise four ways of describing and analysing financial systems. Let us refer to them as the "institutional approach", the "intermediation approach", the "functional approach" and the "systemic approach". As will hopefully become clear, the four approaches are not mutually exclusive. Instead, they build on each other at least to a

\footnotetext{
3 For example, Hicks (1969) argued that the financial system of the UK played an important role in the Industrial Revolution, while Robinson (1952) questioned this view and suggested that the financial system developed as a result of economic growth, i.e., that the causality went in the other direction.

${ }^{4}$ See for instance La Porta et al. (1998), Mayer/Sussman (2001) and Pagano/Volpin (2001) for surveys and Hellwig (2000) for a thorough discussion of the importance of a well-functioning financial system.

5 Different ways of describing and analysing a financial system are discussed at length in Papenfuss (1999).
} 
certain extent. We will then conclude this section by indicating why we advocate using the most comprehensive approach, and by demonstrating in which sense it is in line with the broad concept of the financial system introduced above.

\section{The institutional approach}

As the term suggests, the institutional approach focuses on the existing institutions such as the banks, insurance companies, investment and pension funds, financial markets and the central bank system. Descriptions and classifications of those institutions which in their totality make up the financial sector of a country are the dominant topic in the literature which follows this approach. ${ }^{6}$ Thus the institutional approach is narrow in its focus, and it is not analytical. This characterisation of the institutional approach is not intended to be demeaning, since knowledge of the facts is a prerequisite for any attempt to dig deeper.

In addition to descriptions, classifications and statistical material, work which follows this approach can, and typically does, also offer comments and assessments pertaining to certain features of the various institutions within the financial sector or of the sector as a whole. For instance, it might be supplemented by an evaluation of the degree of competition in the banking sector, of its openness to foreign competitors and of the competition within and between different groups of financial intermediaries; or the transparency of price determination and investor protection in financial markets; or the quality of regulation and supervision.

\section{The intermediation approach}

Although, strictly speaking, no approach can be "purely descriptive" in so far as any description involves the application of at least some analytical criteria which determine what to select and report, it is nonetheless true to say that the institutional approach is primarily descriptive in the sense that it is not explicitly shaped by theoretical considerations concerning, for example, the economic functions of the financial sector and its constituent institutions and their role in the national economy. Conventional economic approaches are different in this respect. One of these, which we do not wish to discuss at this point, is the monetary approach. It regards

\footnotetext{
6 This type of description can be found in numerous textbooks and monographs. See Faugere/Voisin (1994) regarding the French financial system, Buckle/Thompson (1998) regarding the UK financial system, and various chapters in the manual compiled by Obst/Hintner (2000) on the German financial system.
} 
the financial sector, which is composed of the central bank and the commercial banking system, as the apparatus which supplies money to the real economy. ${ }^{7}$

There is another conventional economic approach which can be traced back to the work of Gurley and Shaw ${ }^{8}$ and which emphasises a different role of the financial sector, namely that of intermediation and transformation. In its original form, this approach, which we call the "intermediation approach" for convenience, views the financial sector as composed of banks and other financial intermediaries. Intermediaries go between "surplus spending units", which have more income in a given time period than they themselves want to spend on consumption and real investments during that period, and "deficit spending units", which want to spend more than they have in terms of current income and income carried over from earlier time periods. In simple terms, the surplus units are savers, which is the characteristic role of households, and the deficit units are investors, the typical role of firms and in many cases also of the state. Intermediaries substitute for direct finance by accepting some form of deposits from the savers and providing loans or equity to investors.

Intermediation helps to alleviate some of the problems which would make direct finance difficult. The main problem is that of divergent preferences and economic needs. Typically, savers prefer to have their funds available at short notice, to invest small amounts for relatively short terms, and to have their funds used for purposes which involve a low level of risk. Typical investors want exactly the opposite: they need funds without the threat of having them with drawn unexpectedly; they want to have larger amounts for a longer period of time; and they want to be able to invest them in assets which may include some that entail a higher level of risk. In addition, there is a problem of information and incentives, or of adverse selection and moral hazard, which makes direct finance difficult. Being less informed and less capable of monitoring the use of their funds, savers might simply abstain from directly financing investors, or request compensations which make external financing unattractive for investors.

Intermediaries perform the following functions: they can provide liquidity; they can compensate for a certain mismatch of maturities and amounts, i.e. perform what is referred to as term transformation and lot size transformation; they can act as experts in assessing the economic potential of those who seek funding; and finally they serve as "delegated monitors"

\footnotetext{
${ }^{7}$ For the case of Germany, see Alexander/Bohl (2000) and various publications by the Deutsche Bundesbank, esp. Deutsche Bundesbank (1995). Chapter 5 in this volume book contains elements of this approach.

8 See Gurley/Shaw (1960) and with respect to developing countries Shaw (1973) and McKinnon (1973). For descriptions of financial systems in this tradition, see Kaufman (1997), Ferrandier/Koen (1994) and Bain (1992).
} 
(Diamond, 1984 and the extensions in Diamond and Rajan, 2001, and Tyrell 2003). In performing these functions, the financial sector can create value for the economy.

In an extended version, this approach also takes account of the economic role of financial markets and in particular secondary markets, and thus of the securitisation of financial assets. Financial markets can also perform some of the transformation functions listed above. By doing so, they also mitigate the tensions which would stand in the way of a transfer of a financial surplus from those who want to save to those who have good investment opportunities. Moreover, intermediation in the strict sense of on-balance-sheet intermediation can be combined with intermediation via markets in various ways. ${ }^{9}$

This concept of what financial intermediaries and financial markets do suggests a way of describing and analysing a given financial system in terms of the extent and the effects of intermediation, transformation and securitisation. Evidently, such an approach is much more theory-based than the institutional approach. It not only covers the financial sector, but also includes, as an essential element, the non-financial sectors. Thus it deals with the financial system as a whole. Moreover, it lends itself relatively well to measurement (see Hackethal and Schmidt, 2000/2003) and suggests a straightforward standard for evaluation: a financial system is "better" if it provides more intermediation in the narrow and in the broad sense. However, the intermediation approach is quite selective in terms of what it takes into consideration, which indicates that one could usefully combine it with further extensions. The two approaches to which we turn now can be regarded as relevant extensions.

\section{The functional approach}

While the institutional approach is useful in its emphasis on the given institutional structure, it goes too far in this respect and has some serious weaknesses. As Merton argues, it cannot explain how and why the institutional structure of a financial system changes and how it could evolve over time. More generally, it lacks a deeper understanding of the functions a financial system should perform. While the intermediation approach does have a firm theoretical basis and emphasises functions, it is not entirely satisfactory in so far as it only focuses on two functions of the financial sector, namely intermediation and transformation.

\footnotetext{
9 Allen/Santomero (2001) show for the case of the United States how the role of banks has shifted from acting as financial intermediaries themselves to providing access to capital markets and to the transformation services that the capital markets provide to the economic units of the non-financial sectors of the economy.
} 
Robert C. Merton and various co-authors have developed an alternative to the institutional perspective and, one might add, a generalisation of the intermediation approach. ${ }^{10}$ What they call the functional approach focuses on functions rather than institutions as given and therefore as the conceptual point of departure. In this approach five functions are identified and distinguished from the primary or core function at a less abstract and aggregate level. A financial system provides

1. a way to transfer economic resources through time and across regions and industries, which is singled out as the core function of any financial system,

2. a payments system to facilitate the trade of goods, services and financial claims,

3. a mechanism for pooling resources and for subdividing shares in large-scale indivisible enterprises,

4. a way to manage uncertainty and control risk,

5. price information that can be useful in co-ordinating decentralised decision making,

6. a way to deal with the asymmetric information and incentive problems.

As its advocates claim, the functional approach offers a useful frame of reference for analysing a country's entire financial system; it is more reliable and generates more insights than an institutional approach because the basic functions of a financial system are essentially the same in all economies and are more stable than the identity and structure of the institutions performing them. According to this approach, the analysis of a financial system starts by describing the functions performed by the different elements of a country's financial system and determining how the functions are currently being performed (see Merton and Bodie, 1995, p. 17).

The functional approach has the virtue of abstracting from institutional detail and instead focussing on the underlying economics. However, it may also go too far. A strict application of this approach presupposes that functions are separable, and this assumption may be wrong: On the one side, an arrangement in which a particular type of institution performs multiple financial functions at the same time may be efficient, ${ }^{11}$ and on the other side, specific

\footnotetext{
10 See Merton (1990 and 1995) and Merton/Bodie (1995) for an in-depth description of this approach, and Crane et al. (1995) for various applications.

11 For instance, this can be the case for the institution "bank", which can be understood as the specific combination of the functions of liquidity provision and relationship lending (Diamond and Rajan (2001)). See Rajan (1996) for a similar critique of the functional approach with respect to the institution "commercial bank".
} 
configurations of institutions may be required to reduce frictions which would otherwise hamper the allocation of resources and thus lower the performance of a financial system. This requirement, namely the complementarity between different elements (institutions) of a financial system, will be discussed in more detail in the next subsection. As a result, there are major trade-offs and interrelationships between the different functions described above and the different institutions performing those functions (see Allen and Gale (2000) for analyses of these trade-offs). In this respect different financial systems may have different strengths and weaknesses, which the functional perspective seems hardly capable of grasping.

\section{The systemic approach}

A systemic approach aspires to accomplish just that: It describes and analyses a financial system in terms of the interrelations between its elements and the impact which these interrelations have on the performance of the system as a whole. In a systemic perspective, a financial system is an ordered set of complementary and possibly consistent elements or subsystems. What is the meaning of "complementarity"? Two (or more) elements of a system are complementary to each other

- if the positive effects of the values taken on by the elements mutually reinforce each other in terms of a relevant evaluation function, and the negative effects mutually mitigate each other, i.e.,

- if a higher value for one element increases the benefit yielded by an isolated small increase in the value for the other element (and vice versa), and

- if, as a result, the "quality" or the "economic value" of a system depends on the values taken on by its (complementary) features being consistent with each other or, to put it simply, on the values "fitting together". 12

Whether the elements or subsystems of a given system are complementary is determined by theoretical considerations. In the case of financial systems, such considerations would have to show that elements such as the role of banks in the financial sector, the financing patterns of corporations and the governance structure of big corporations, as well as the role of financial

\footnotetext{
12 There are much more formal ways of defining and characterising the concept of complementarity, which use the mathematical apparatus of lattice theory; see Fudenberg/Tirole (1991), Topkis (1998) and Hackethal (2000). The concept has been popularised in the economic literature by the work of Milgrom and Roberts in the context of organisational design; see e.g. Milgrom/Roberts (1990, 1995a, 1995b) but also Aoki (2001). For an application of the concept of complementarity to the field of financial systems see Aoki/Patrick (1994) and Schmidt/Hackethal/Tyrell (2002).
} 
markets as compared to that of intermediaries, the structure of the pension system and certain parts of the legal system are complementary to each other. This can indeed be shown to be the case. ${ }^{13}$ Thus it is accurate to say that all financial systems are shaped by the complementarity of their main elements. Moreover, theoretical considerations allow the conclusion that there may not be more than a few or even only two "efficient" types of financial systems, as is reflected in the well-known classification of financial systems into two groups, depending on whether they are perceived as being bank-based or capital market-based.

However, complementarity implies merely that a potential exists: economic benefits may accrue, but only if the main elements of a (financial) system take on values which fit together well. This potential will not necessarily be realised. This is precisely the aspect covered by the concept of "consistency". We refer to a system made up of complementary elements as being consistent if the benefits of complementarity are exploited and if, therefore, a small change in the value taken on by an individual feature, or by several features, does not permit an improvement in terms of the objective function or the evaluation function. Whether or not a given financial system is consistent is an empirical question.

As a consequence, the financial system of a country can be characterised by determining which of the known types of financial systems (defined on the basis of their complementary elements) it conforms to - if any all - and by investigating to what extent its elements are indeed consistent.

Of course, these definitions of complementarity and consistency presuppose that there is a standard of measurement with which systems can be evaluated - at least approximately - in terms of the benefits they offer, and that the values taken on by the elements can be measured at least in the weak form of an ordinal ranking and/or that it is possible to distinguish between "polar" values. The standard for assessment might be a general level of economic welfare or the contribution which the financial system makes to economic growth; but it might also be the extent to which the functions of financial systems listed by Merton and his co-authors are performed, and also how well they are performed.

A consistent system of complementary elements is in a state of (static) equilibrium. Typically, the key elements of systems characterised by complementarity include multiple equilibria or

\footnotetext{
13 See Hackethal/Tyrell (1999), Hackethal/Schmidt (2000) and Tyrell/Schmidt (2001) for various combinations of the financial system elements listed here.
} 
local optima. ${ }^{14}$ In most cases it is impossible for the individual actors operating in the system to judge whether a local optimum is also the global optimum. This feature has important implications for the development of financial systems and especially for the issue of the convergence of different financial systems over time. With respect to the German financial system this aspect will be taken up in the final chapter of this book.

The twin concepts of complementarity and consistency would seem to give a more precise meaning to what is colloquially called "a real system", as it is highly plausible to assume that one's assessment of individual elements, and indeed of a specific change in one element, depends in a crucial way on the values which the other elements of the system take on. What are the implications of this insight for the task of describing and analysing a given financial system? Unfortunately, a formal proof of complementarity and consistency based on the mathematical theory which underlies the theory of complementarity cannot be performed in practice because it would require much more information than is available. However, one can attempt to describe a given financial system informally in such a way that complementarities which are presumed to exist become visible. If one can show that different key elements of the financial system in question fit together in a specific way, then this system is also likely to be consistent, and it can be classified as belonging to one of the two types of financial system distinguished above. Thus, this investigation should be a part of the characterisation of any financial system.

\section{Implications}

All four of the approaches discussed above have their merits, and each of them is taken into account in the following chapters of the book as well as in the following section of the present chapter. However, as the systemic approach is the most comprehensive one, we will now attempt to outline the most important features of the German financial system using the concept of complementarity. We will argue that these features together constitute, or at least did constitute until quite recently, a system of complementary elements, each of which fits together with the others, thus making the others more effective than they would otherwise be.

\footnotetext{
14 For this reason it is important to determine the key elements of a financial system. If a change in the value of an individual element would inevitably undermine the consistency of the whole system, we refer to this element as a key or core element. For instance, a fundamental change in the character of a country's pension system from a pay-as-you-go system to a capital-funded system would lead to an inconsistency if that country's financial system were bank-based. See Tyrell/Schmidt (2001) for more details.
} 


\section{The German financial system: An overview of its characteristic features}

\section{Introduction}

We start our overview of the German financial system with a brief description of the financial sector, including the regulatory environment, using the institutional approach. In subsection 3, we then look at the different functions which a financial system has to perform. We describe which part of the financial system fulfils which functions, and especially how resources are collected, allocated and controlled in the German financial system. The main focus in this subsection will be on the role of banks as financial intermediaries, on the patterns of German corporate finance, and on corporate governance in Germany. However, this section also includes a brief characterisation of the savings behaviour and portfolio choice of German households and of the German pension system, two topics which are not covered specifically by individual chapters in the present book. Thus subsection 3 applies both the narrower intermediation perspective and the broader functional perspective to the case of the German financial system.

In subsection 4, we bring the different elements together and trace a picture of the overall financial system, identifying its peculiarities and especially its systemic character, as we perceive it. We will argue in this subsection that in the mid-to-late 1990s, i.e. before the major stock market rally of the late 1990s and the ensuing downward spiral, the German financial system was indeed a consistent system. Since that time, however, the German financial system has undergone considerable changes, and these recent developments may have distorted the picture of complementarity and consistency. More precisely, they would appear to cast doubt on the conceivable proposition that the German financial system is still today a largely consistent one. However, we make no such proposition here. Whether the German financial system still is what it seems to have been only seven, or even only five years ago, or whether it has recently changed its character in a fundamental way is too complicated a question to be discussed seriously within the limited space of this section. In the concluding chapter of this book, the two editors will explain why both possibilities appear plausible - and why it is also too early to take a firm stand on this issue. The chapters that follow will present most of the material on which such an assessment might be based. Thus the present chapter serves as a point of reference for the following chapters. To a certain extent, this section and especially subsection 4 characterises not the German financial system as of the time of writing, but rather that of the mid-to-late 1990s. Through the use of present and past tense, as well as occasional footnotes and cross references, we indicate which of the features of the 
German financial system described in this section have changed substantially during the last half-decade.

\section{The institutional perspective}

The financial sector of a country encompasses the financial intermediaries, which can be subdivided into banks, non-bank financial intermediaries (NBFIs) and financial markets, and also the regulatory environment in which these institutions operate. It is in this sequence that we now consider each of these elements in turn.

\section{a) Banks}

In the mid-1990s the German banking system exhibited characteristics, especially its structural complexity and the power of its banks, that differentiated it from many other banking systems in industrialised countries. ${ }^{15}$ A bank, in legal terms a "credit institution", is defined in Article 1 of the Banking Act of 1961 as any enterprise which is professionally engaged in the activities of accepting deposits, making loans, discounting bills, providing securities brokerage services and trust (safe custody) services, factoring, financial guarantees, and funds transfer or payment (giro) services as well as providing other services which the relevant authorities might define as banking services. According to this broad definition, there were approximately 3,700 legally independent banks with more than 48,000 banking offices in Germany in 1995. ${ }^{16}$ Thus, in terms of the large numbers of banks and banking offices, Germany was, and still is, one of the most heavily "banked" economies in the world. The number of banks in Germany has declined in recent years, but is still large by international standards.

The vast majority of the banks are universal banks, which means that they are engaged, to a greater or lesser extent, in all of the activities listed above, plus typical investment banking services and the provision of insurance products through subsidiaries or closely connected insurance firms.

With respect to their ownership structure, the German universal banks can be subdivided into three categories: private commercial banks, savings banks, and cooperative banks. Only about 330 of Germany's banks, or roughly $10 \%$ of the total number of banking institutions, were private commercial banks, and thus, at least based on their ownership structure and their legal

\footnotetext{
15 For a detailed description of the German banking sector, see Büschgen (1993), Süchting/Paul (1998) and Hartmann-Wendels et al. (1998).
} 
status, profit-maximising entities. ${ }^{17}$ In 1995, the group of private commercial banks included the three major publicly listed banks Deutsche Bank, Dresdner Bank and Commerzbank; the regional commercial banks with extensive branch networks; and the few remaining private banking outfits. 18

Table 2-1 below provides information on the fractions of the three major banking groups with respect to the number of legally independent institutions, total bank assets, and bank branches for both 1995 and 2001.

Table 2-1: Structural figures for the German banking sector

\begin{tabular}{|c|c|c|c|c|}
\hline \multicolumn{5}{|c|}{1995} \\
\hline Bank group & $\begin{array}{c}\text { Balance } \\
\text { sheet total, } \\
\text { DM million }\end{array}$ & $\begin{array}{l}\text { Percentage } \\
\text { of balance } \\
\text { sheet total }\end{array}$ & $\begin{array}{l}\text { Number of } \\
\text { credit } \\
\text { institutions }\end{array}$ & $\begin{array}{l}\text { Domestic } \\
\text { branches }\end{array}$ \\
\hline $\begin{array}{l}\text { Private commercial banks } \\
\text { Big banks }\end{array}$ & $\begin{array}{r}2,218,356 \\
978,322 \\
\end{array}$ & $\begin{array}{l}27.4 \% \\
12.1 \% \\
\end{array}$ & $\begin{array}{c}331 \\
3 \\
\end{array}$ & $\begin{array}{l}7,305 \\
3,624 \\
\end{array}$ \\
\hline Savings bank group & $3,046,470$ & $37.7 \%$ & 637 & 19,504 \\
\hline Credit cooperative group & $1,149,666$ & $14.2 \%$ & 2,595 & 17,248 \\
\hline All other categories & 1.675 .208 & $20.7 \%$ & 221 & 4,167 \\
\hline Total & $8,089,700$ & & 3,784 & 48,224 \\
\hline \multicolumn{5}{|c|}{2001} \\
\hline $\begin{array}{l}\text { Private commercial banks } \\
\text { Big banks }\end{array}$ & $\begin{array}{l}2,458,055 \\
1,648,863\end{array}$ & $\begin{array}{l}33.2 \% \\
22.3 \%\end{array}$ & $\begin{array}{c}303 \\
4\end{array}$ & $\begin{array}{l}5,576 \\
2,369\end{array}$ \\
\hline Savings bank group & $2,575,194$ & $34.8 \%$ & 547 & 17,094 \\
\hline Credit cooperative group & 783,972 & $10.6 \%$ & 1,623 & 14,602 \\
\hline All other categories & $1577 \cap 28$ & $21.3 \%$ & 222 & 3,867 \\
\hline Total & $\overline{77,394,249}$ & & 2,695 & $\overline{441,139}$ \\
\hline
\end{tabular}

Source: Deutsche Bundesbank (1996, 2002)

The private commercial banks dominate the securities trading and custody business and also play a dominant role as investment bankers on the IPO market. In addition, especially the big joint stock banks hold substantial interests in commercial enterprises and other financial

16 See Deutsche Bundesbank $(1996,2002)$ for most of the data in the following description. Chapter 8 of the book explains the extent to which, and the reasons why, the number of banks has decreased since then.

${ }^{17}$ In terms of the volume of bank assets under their control, this group represented $27 \%$ of total German bank assets in 1995. The market share of the so-called big banks (Grossbanken) amounted to only $12 \%$.

18 Since the merger of the two large exchange-listed Bavarian banks in 1998 to form Hypovereinsbank, the banking statistics of the Deutsche Bundesbank have included it as a fourth "big bank". In addition, the insurance company Allianz took over the Dresdner Bank in 2001, which is therefore no longer publicly listed. 
institutions that provide specialised and mortgage banking services. Regional commercial banks have a strong local presence. Apart from being universal banks, they are in many cases strongly engaged in some specialised activity, e.g., housing finance. Smaller private banks typically have the legal form of a partnership and specialise in the financing of a particular industrial sector or in the provision of selected banking services to wealthy customers, such as investment advisory and trustee services. In the mid-1990s, only about 60 branches of foreign commercial banks operated in Germany, representing only $2 \%$ of total banking assets. One group of foreign banks mainly provided their services to German subsidiaries of foreign firms, while another group plays an important role in the various fields of investment banking.

In terms of total assets and banking offices, the savings banks group is the biggest group in the German banking sector. It comprises three layers of institutions, consisting of about 600 local savings banks, 13 regionatlevel banks (called Landesbanken or Landbanks, "Land" being the term given to each of the states that make up the Federal Republic) and one institution at the top of the system. With only a few exceptions, savings banks are owned by the public sector, i.e. municipalities, districts and federal states. This implies that the public sector bears liability if the savings banks run into financial difficulties and is also obliged to make sufficient capital available to them. For this reason and because of their legal mandate, savings banks are not strictly profit-maximising entities.

Local savings banks operate only in their designated region and thus they hardly compete with each other. They provide local customers with a wide range of banking services, excluding only those services that they cannot provide efficiently because are too small, and those that are prohibited by the relevant savings banks law. This is where the Landbanks come into play. Moreover, the Landbanks serve as a clearing-house for the local savings banks as well as holding their excess liquidity reserves, and are typically also the "house bank" of the respective Land. They are fully-fledged universal banks and wield enormous power based on the strong branch presence of the savings banks.

The third important group is the cooperative banking group, comprising a larger number of independent institutions than any of the other groups. In 1995, there were nearly 2,600 local cooperative banks with 17,000 branches. But typically these banks were rather small: the entire cooperative group represented only $14 \%$ of total German banking assets. Cooperative banks are member-owned, and according to their by-laws their main function is to support the business of their member-owners. Thus, these institutions too are not standard profit-maximising entities. In recent years, a wave of intra-sectoral mergers has greatly reduced the 
number of local cooperative banks, and the upper levels of the cooperative banking system have been restructured.

These three banking groups also shape the German payment system. In Germany credit transfers and direct debits are the predominant form of payment transactions. Nearly every bank belongs to one of the banking groups which at each case operate their own giro network to process retail payments. ${ }^{19}$ The processing in these networks is usually carried out on a bilateral basis with settlements effected by one or more of the banking group`s central institutions. This stands in sharp contrast to most other industrialised countries where because of other banking structures typically cheques are used in non-cash payments. ${ }^{20}$

Apart from these three main categories of (universal) banks, banks with a somewhat narrower scope also play an important role in Germany. There are about 200 non-universal public and private banking institutions representing more than $20 \%$ of total German banking assets. One important subgroup here are the public and private mortgage banks. These institutions enjoy a special status and the privilege of being authorised to issue mortgage bonds (Pfandbriefe), i.e., asset-backed securities with long maturities. Furthermore, the group of specialist banks includes various government-funded banks with special mandates to support economic development in Germany and in other countries; and also the Deutsche Postbank AG.

Let us briefly summarise the main characteristics of the German banking system as outlined above. $^{21}$

1. It was - and still is - dominated by universal banks, almost all of which are genuine universal banks in the sense that they are not merely financial conglomerates, but rather accommodate almost all divisions within a single institution.

2. The majority of institutions are not bound to the principle of profit-maximisation. Most banks provide the full range of financial services, but in fact - aside from a few exceptions, notably some of the so-called big banks - they concentrate on retail deposit-taking and lending. Not only urban but also rural populations enjoy good access to these banking services.

3. Competition is greater between the different groups of banks than within each group.

\footnotetext{
${ }^{19}$ Deutsche Postbank AG is also a big player in the payment services market because they operate with more than 14,000 branches a big giro network.

20 See European Central Bank (2002) for more details.
} 
4. The clear predominance of banks is also reflected in the fact that the ratio of banking assets to GDP is relatively high, compared to other industrialised countries and compared to corresponding measures for the stock market.

5. In purely quantitative terms, the three (or four) big German banks do not seem to be as important as the biggest banks in most other countries. Yet this assessment is no longer strictly true if one takes account of the other roles they play, in addition to lending and deposit-taking.

\section{b) Non-bank financial intermediaries}

By international and especially by Anglo-Saxon standards, non-bank financial intermediaries (NBFIs) or institutional investors 22 were still a relatively small segment of the financial sector in Germany in the mid-1990s. ${ }^{23}$ This applies in particular to investment funds, which have considerably gained in importance since then, however.

NBFIs in Germany can be subdivided into two main groups: insurance companies and investment companies. Insurance companies are the largest group of NBFIs. Especially life insurance companies are of interest here because they are important institutional investors that manage savings on behalf of small investors. ${ }^{24}$ In the mid-1990s, domestic insurance companies dominated the German life insurance market, ${ }^{25}$ and $46 \%$ of total premium volume was generated by the four biggest companies. Nevertheless, compared to other industrialised countries, the market concentration was still low (see also Albrecht/Schradin, 1999).

The portfolio composition of the German life insurance industry shows some interesting peculiarities. $57 \%$ of the funds were invested in loans and bonds - especially loans to banks, bank bonds and government bonds - but a mere $17 \%$ in domestic equities and virtually nothing in foreign assets. ${ }^{26}$ It is important to add here that there are close connections between

\footnotetext{
21 Banks and bank-client relations are discussed at greater length in the chapters by Andreas Hackethal and by Elsas and Krahnen in this book.

22 As Raimond Maurer does in the chapter on institutional investors in Germany in this book, we follow Davis/Steil (2001) in using the term institutional investors as a synonym for NBFIs.

23 See the figures in Davis/Steil (2001, p.7/8) and Schmidt/Hackethal/Tyrell (1999).

24 In the mid-1990s, pension funds were virtually non-existent in Germany because of the structure of the German social security system. After the pension reform legislation of 2001 this is slowly changing.

25 In 1997 international companies had a 13\% share of total premium volume. See Albrecht/Schradin (1999) for these and the following figures.

26 See Davis/Steil (2001, p.33). The fraction invested in shares had increased in the late 1990s, but never came close to the level in Great Britain, for example. For details, see the chapter on institutional investors in this book.
} 
the insurance and banking industries which manifest themselves in cross-holdings of equity and seats on the respective supervisory boards (see Böhmer, 2001).

The investment industry was a latecomer to the German financial sector. With a mere $9 \%$ of GDP, the volume of total assets under management in 1998 was far below the comparable figures in the UK, the US or France. There are two types of investment funds: so-called special funds, which are administered only for institutional investors; and public funds, which are offered to the general public. In the late 1990s about two-thirds of the capital managed by the investment industry was held in special funds. ${ }^{27}$

In the context of the German investment business it is important to distinguish between two types of legal entity, namely the investment companies which manage funds, and the funds themselves. The investors who provide the capital which is administered by this type of institutional investor are shareholders in the fund, but not shareholders in the investment company. In the mid-90s, and still today, the shareholders of the investment companies were mostly banks - in many cases a single bank or a single banking group - and these banks would also typically serve as marketing channels for the shares in their investment funds. The dual role of the sponsoring banks gives them a great deal of influence on the business decisions of the investment companies, and may create the basis for conflicts of interest between the banks as shareholders in the investment companies and those in the funds. ${ }^{28}$

The investment behaviour of German investment funds is, on average, rather conservative. In 1995 only about $25 \%$ of the assets of all investment funds were invested in domestic or foreign equities, while the overwhelming proportion went into bank and government bonds or into liquid assets. It is surely not too far-fetched to assume that the investment policy of the investment industry corresponded to the fundamental interest of the banks in maintaining their role as lenders and underwriters, and also reflected the influence which the banks have on other parts of the German financial sector.

\footnotetext{
27 The insurance industry was by far the largest category of investors in special funds in 1999, followed by credit institutions (Laux/Päsler (2001)).

28 The empirical results in Baums/Theissen (1999) do not show that this potential conflict of interest has an adverse impact on the performance of the funds.
} 


\section{c) Financial markets}

In an institutional sense, financial markets comprise the primary and organised secondary markets for securities and other tradable financial instruments, and also the money market. In what follows, we mainly focus on the organised markets for stocks and bonds. ${ }^{29}$

Although in terms of absolute capitalisation the German stock market was the fourth largest equity market after the US, Japan and the UK in the mid-1990s, in comparison to the size of the German economy it was, and still is, relatively small. ${ }^{30}$

In 1995, only 678 domestic companies were listed on any of the German stock exchanges. IPO activity was virtually non-existent. 31 The number of listed German corporations had been declining for years. If a corporation did aspire to go public and be listed, then typically one of the big commercial banks accompanied this new issue as the investment bank and underwriter. Thus, all in all, as a source of funding and as an investment vehicle, the organised stock market was indeed "underdeveloped".

Until the early 1990s, the limited importance of the stock market was reflected in its institur tional structure. The main stock exchange was located in Frankfurt, but the overall German stock market was highly fragmented, consisting of a number of individual exchanges, which were overly regulated in certain respects - e.g., in terms of their listing requirements - while investor protection was still in its infancy. A law prohibiting insider trading had been introduced as recently as 1994, and it was only then that an institution designed to implement this and other investor protection measures began to take shape. ${ }^{32}$

The German stock exchange system consisted of three market segments, the official market (amtlicher Markt), the semi-official market (geregelter Markt) for small caps and the overthe-counter market (Freiverkehr). The new market (Neuer Markt) for young technologyoriented stocks was only created in 1997. In their role as the majority owner of the Deutsche Börse AG, which runs much of the German stock exchange system, the banks played, and in fact still play, a dominant role in determining the overall development and even the

\footnotetext{
29 Some aspects of the German money market are discussed in the chapter by Andreas Worms on the monetary transmission mechanism in this book.

30 See DAI-Factbook 2001 for most of the data used in this section. The market capitalisation/GDP ratio increased considerably in the stock market boom of the late 90s but fell again in 2001/2002. See the chapter by Theissen in this book for more details.

31 For details, see the chapter by Franzke, Grohs and Laux in this book.

32 See Nowak (in this book) for an account of how investor protection developed in the past decade in Germany. The author argues that since the turn of the millennium it has no longer been appropriate to speak of an underdeveloped stock market system as far as investor protection is concerned.
} 
operational policies of the stock exchanges. In 2002, the system of market segments was revised. As a consequence of a series of failures and scandals, the Neuer Markt, which had attracted considerable attention and enjoyed great popularity for a time, is to be closed down in the course of 2003.

In the mid-1990s, turnover on the German stock exchanges was also still low by international standards, and trading was heavily concentrated, focusing on just a few "blue chips". Liquidity was modest for various reasons. On average, the free float was, and still is, reduced by the fact that stock ownership is heavily concentrated and cross-holdings are pervasive with wealthy families, non-financial corporations and banks and insurance companies as the biggest blockholders (see Franks and Mayer, 1995, and Barca et al, 2001). The general public did not show any great interest in the stock market in the early to mid-1990s, as is evidenced by the fact that the share of the German population which owns stock directly or indirectly was much lower than in most comparable countries.

As Erik Theissen explains in his contribution to this book, the German stock exchange seems to have improved greatly since the mid-1990s as far as its role and its institutional structure are concerned, whereas its role as an outlet for savings and as a source of funding seems to be limited to this day.

In terms of the value of outstanding securities the German bond market was and still is larger than the stock market. There are five main categories of bonds in the German markets, with almost all of the capital raised in the bond market flowing to banks and the public sector. Industrial bonds were virtually non-existent on the domestic market in the mid-1990s. DM bond issues on the Euromarket were larger but still small by international standards. The fact that banks did the underwriting of every new bond issue of the German government via a fix consortium consisting of all bigger German banks is an additional indicator of the dominance of the banks over the entire financial sector. ${ }^{33}$ With the advent of the Euro, the market for industrial bonds starts to become more lively now.

Besides the bond market there is an important market in "certificates of indebtedness" (Schuldscheindarlehen). Schuldscheine are not securities but negotiable promissory notes or loan certificates with variable terms and maturities of up to 15 years. They are issued in a

\footnotetext{
33 This federal bond consortium was abolished in 1998. Major federal securities are now auctioned through the "Bund Issues Auction Group". See Deutsche Bundesbank (1998) for further details.
} 
private placement market but actively traded over-the-counter. As the minimum denomination has traditionally been DM 1 million, the main investors in this market have been institutions.

\section{d) The regulatory environment}

Until the end of the last millennium, financial regulation and supervision was fragmented, and there were substantial differences between banking, capital markets and insurance.

Regulation of the banking sector is based primarily on the German Banking Act of 1961. As a consequence of various amendments to the Banking Act in the 1960s, the overall regime had been relatively liberal for quite some time. Earlier than in most other European countries, the establishment of banks and bank branches had been deregulated, and interest rates were fully liberalised as early as 1967. And apart from solvency-related provisions, there are also no restrictions on lending. Banks are free to invest in non-financial corporations and to engage in a broad spectrum of banking and bank-related activities, including almost all aspects of investment banking. Thus, the general regime provides the basis for true universal banking. Only insurance and mortgage banking activities have to be carried out via institutions with a separate legal identity. As far as the substance of regulatory practice is concerned, the emphasis has long been on capital adequacy and solvency regulation.

The overall responsibility for bank supervision rested with the Federal Banking Supervisory Authority (FBSA), an independent government authority under the auspices of the Ministry of Finance. In its practical work, the FBSA was expected to cooperate closely with the Bundesbank and its regional affiliates, the so-called Landeszentralbanken, which were responsible for on-site inspections. Overall, it seems fair to say that the German system of banking regulation and supervision was well developed and functioned well. It is indicative that between 1974 and 2001 there was no event in Germany which could be classified as a banking crisis.

In comparison to banking, the insurance industry was much more heavily regulated. In particular, the investment of funds by insurance companies was tightly restricted to assure solvency and liquidity at all times. As a result, most of the funds mobilised by the insurance companies were placed with banks and investment funds. In addition, activities associated with different insurance products, especially life insurance and property and liability insurance, have to be carried out through different legal entities. This is why German insurance companies tend to be complex groups with many subsidiaries.

Until the mid-1990s, regulation of the stock market was rather neglected. Rules favouring transparency and restricting insider trading were virtually non-existent, and the disclosure of 
price-sensitive information was rather weak. Not until then did the German authorities begin to transpose EU directives into national law. Thus, the stock market de- and reregulation was initiated by foreign rather than domestic interest groups.

The Deutsche Bundesbank opposed the deregulation of the money market, because it used this market as its primary means of controlling monetary growth. Consequently, commercial papers and money market mutual funds were only gradually introduced in the 90s. Thus, in effect - and this may or may not have been intended - the Bundesbank protected the commercial banks against competition from other instruments and institutions. ${ }^{34}$

The institutional structure of financial regulation and supervision changed in 2002. Following the example of the British FSA, the German government created a new institution, the Bundesaufsichtsamt für das Finanzwesen (BAFin), integrating the traditional supervisory functions for the banking, insurance and securities industries under one roof.

\section{The functional perspective}

The primary function of each financial system is to allow savings to be invested in wealthcreating projects, typically undertaken by firms. This process has many dimensions which should be taken into consideration when describing the German financial system. For instance, one should know how firms obtained funds and financed investments in Germany. Another perspective on how the German financial system operates can be obtained by looking at savings and the holding of financial and real assets by private households. In addition, one should ask what role different types of financial institutions (banks, non-bank financial intermediaries and organised capital markets) play with respect to the functions of intermediation and transformation. These questions focus on the structure and the functions of the financial sector. Equally important are the risk-sharing mechanisms associated with the channelling of funds from units with surpluses to units with deficits and the way information is acquired and used in the process of allocating resources. In this section, these aspects of the financing process will be surveyed, applying both the narrower intermediation approach and the wider functional approach to describing and analysing a financial system.

\footnotetext{
34 The Deutsche Bundesbank itself summarised its monetary policy design as follows: "Owing to their preeminent position, credit institutions play a key part in the transmission of monetary stimuli, and provide the most important starting point for central bank policy measures" (Deutsche Bundesbank (1995), pp. 43-44).
} 


\section{a) Intermediation and the distribution of roles in the financial sector}

In order to characterise the structure and the functions of the financial sector in Germany in quantitative terms, we will rely primarily on intermediation ratios. ${ }^{35}$ This type of ratio is based on the notion of an economy as a collection of sectors which exchange real goods, services and funds with each other. The implementation of transactions entailing financial resources implies that funds flow between the parties, the total amount of these flows being manifested in stocks of claims held by certain sectors which are matched by stocks of liabilities incurred by other sectors.

Intermediation ratios (IRs) are defined and calculated on the basis of the stocks accumulated over several periods. They measure the share of the claims - or liabilities - of a sector (or group of sectors) which are claims on - or liabilities to - the entire financial sector or, more specifically, on the banking sector as a percentage of the total claims - or liabilities - of the sector under consideration vis-à-vis all other economic sectors. Intermediation ratios provide an indication of how important the financial sector or, more specifically, the banking sector is in channelling funds from surplus to deficit units. As a time series, an intermediation ratio provides an indication of how this role develops.

Central banks or the respective national statistical offices compile records of the financial flows within an economy. These statistics provide an ideal source of data for the computation of the two types of ratios. Given that these figures distinguish between sectors rather than individual economic agents, the study of intermediation ratios can only deal with intersectoral stocks, but not with intra-sectoral stocks. In the official flow-of-funds statistics, the financial sector is typically subdivided into the banking sector on the one hand and the NBFI sector on the other hand. See Hackethal, 2000, for a detailed discussion of the database.

In Charts 1 and 2, the most important intermediation ratios have been plotted for Germany covering the time period from 1981 to1998. The General Asset Intermediation Ratio (abbreviation: Asset-IR and shown in Chart 1) and the General Liability Intermediation Ratio (which is by construction numerically almost indistinguishable from the Asset-IR and is therefore not shown) reflect the highest degree of aggregation. The Asset-IR indicates what fraction of the total financial claims of all non-financial sectors is accounted for by claims on

\footnotetext{
35 The results presented in this section are an extension of those reported in Schmidt/Hackethal/Tyrell (1999), where the financial sector structures of different industrialised countries in the 80 s and 90 s are compared. See this study for details concerning the data and the methodology.
} 
the entire financial sector. Correspondingly, the Liability-IR represents the fraction of all intersectoral liabilities of the non-financial sectors that are liabilities to the financial sector. ${ }^{36}$

The general intermediation ratios for all non-financial sectors can be disaggregated in three ways to yield partial ratios and thus more detailed information. First, the investment and financing behaviour of individual non-financial sectors can be considered separately. For example, the Asset-IR of Households (Chart 1) shows which fraction of the total financial assets of households consists of claims on the financial sector. Correspondingly, the LiabilityIR of Firms (Chart 1) shows which fraction of the inter-sectoral liabilities of firms is owed to financial intermediaries. Second, it is possible to address the question of how the claims on (liabilities to) the financial sector break down into claims on (liabilities to) banks on the one hand and NBFIs on the other. Thus, for example, the Asset-IR with Banks (Chart 2) indicates which portion of the total financial assets of the real sectors is invested with banks, and the Liability-IR to Banks shows the fraction of liabilities that is owed to the banking sector. Finally, these two forms of disaggregation can be combined to produce a third form which is even more detailed. The Asset-IR of Households with Banks (Chart 2) indicates the role played by banks in mobilising the financial assets of households. In an analogous fashion, the Liability-IR of Firms to Banks provides a measure of the role of banks in enterprise financing.

\footnotetext{
36 If the financial accounts of the financial sector were balanced - that is, if financial institutions had no real assets - then, following the logic of a flow-of-funds analysis, the financial assets of the non-financial sectors would necessarily be equal to the total value of their liabilities. In that case, the Asset-IR and the Liability-IR would have to be identical. In the case of Germany, the values of these two ratios are nearly identical.
} 


\section{Chart 1: General Intermediation Ratios}

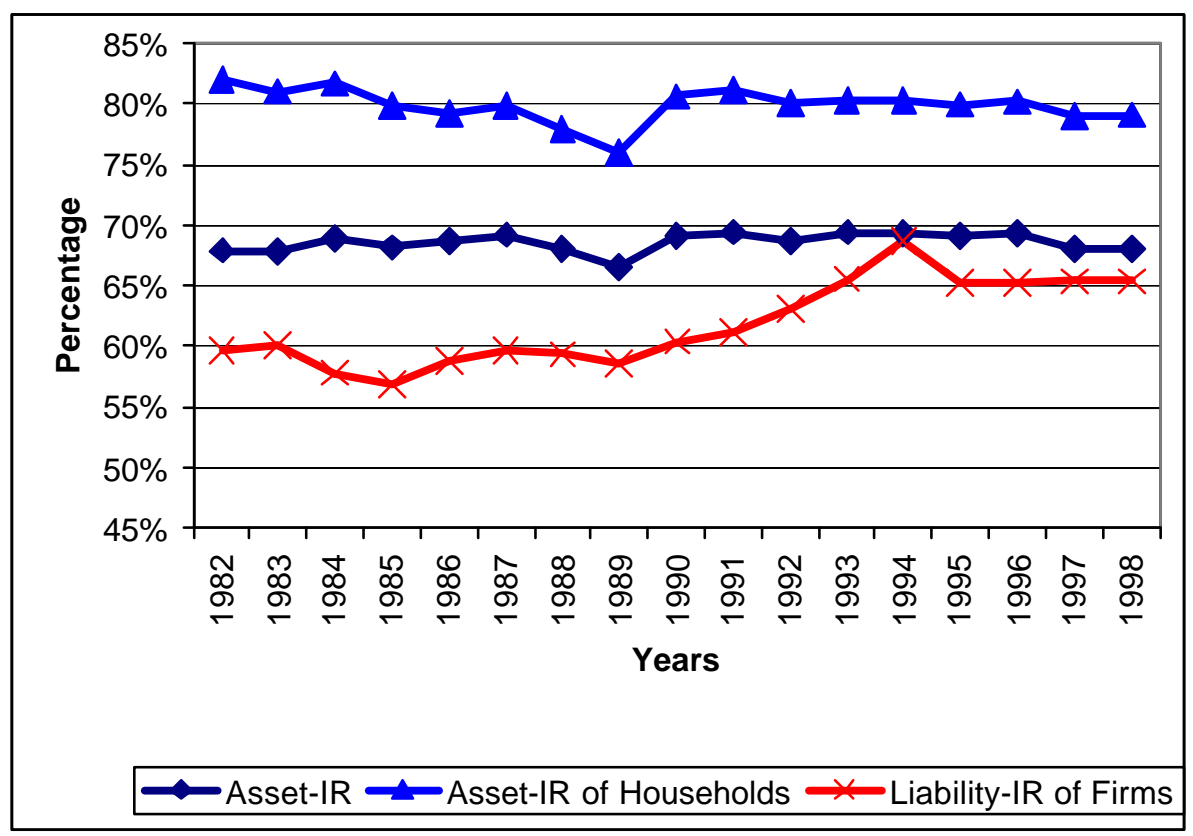

Source: Schmidt/Hackethal/Tyrell (1999)

\section{Chart 2: Partial Intermediation Ratios}

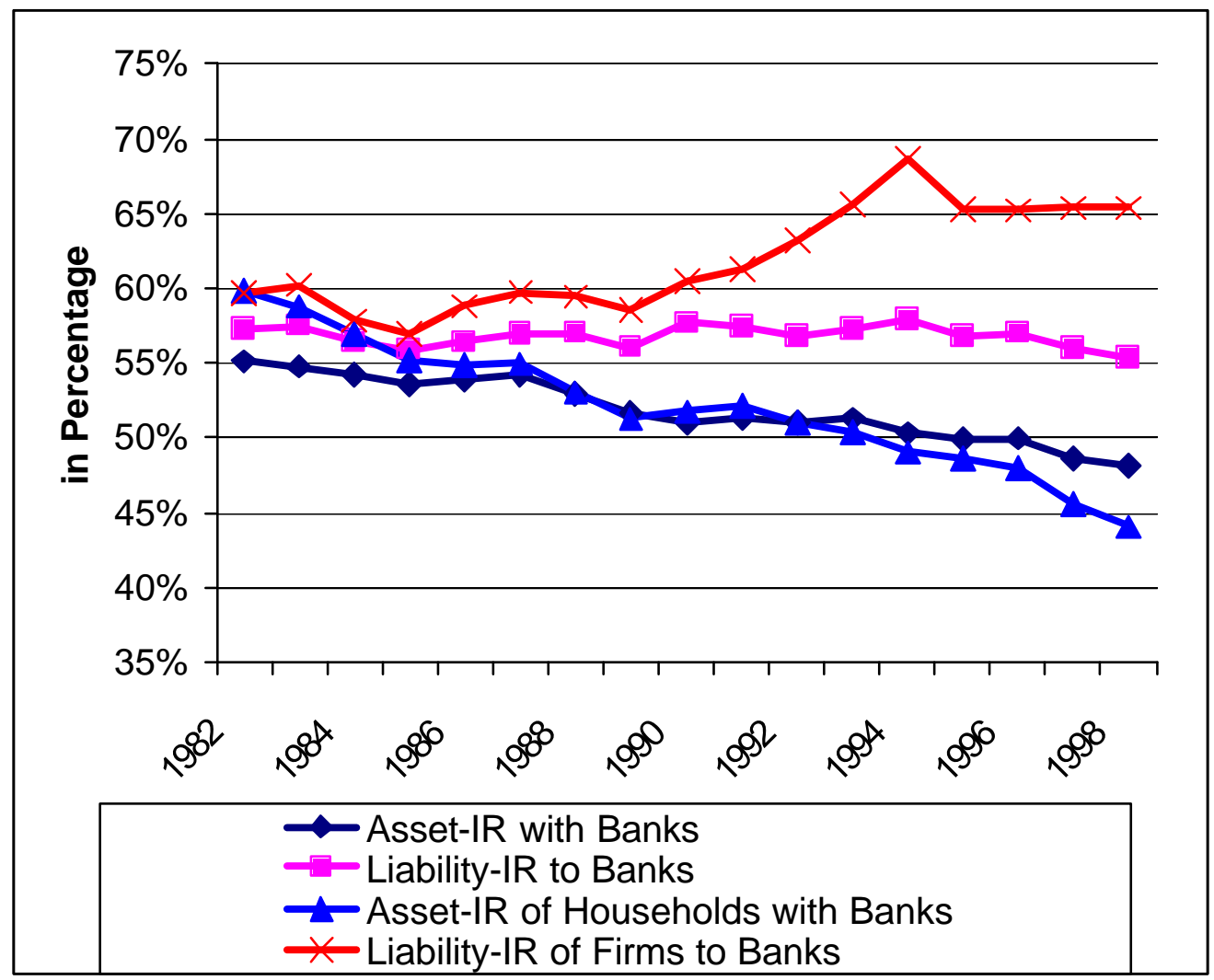

Source: Schmidt/Hackethal/Tyrell (1999) 
Taken together, these ratios show that at least until the end of the 1990s banks were the dominant financial institutions in terms of their role in channelling funds from households to firms. Private households invested their funds mainly with banks, using traditional non-securitised financial instruments, and to the extent that firms financed themselves externally, they did so mainly by taking on bank credit. What may be most surprising is the stability of the intermediation ratios over time. Most importantly, with the exception of housholds' deposits with banks, intermediation in general and bank intermediation in particular has hardly changed over time. In an international comparison, the high level of bank intermediation, as measured by the Asset-IR and the Liability IR vis-à-vis banks, stands out as a characteristic feature of the German financial system. (See Schmidt/Hackethal/Tyrell (1999) and Hackethal (2001) for more details.)

An additional point emerges if we look at the intermediation ratios of the banking sector itself, which can be calculated in a manner analogous to that used to compute the IRs of the non-financial sectors if total inter-sectoral assets or total inter-sectoral liabilities are selected as the denominator. The Asset-IR of Banks shown in Chart 3 indicates the extent to which banks do not channel their funds directly to the real sectors, but rather provide them first to other financial intermediaries, which, by definition, are NBFIs. The Liability-IR of Banks in Chart 3 shows the fraction of banks' funding which they obtain from NBFIs. The higher the values for these two ratios are, the longer is the chain of intermediation. In Germany, this chain of intermediation became longer in the course of the 80s and 90s. Since the early 1980 s there has been a clear tendency on the part of banks in Germany to increase the proportion of their funding that they obtain from NBFIs. However, there has not been a corresponding change on the banks' asset side. As providers of loans the banks do not seem to have lost ground. 


\section{Chart 3: Intermediation Ratios of Banks}

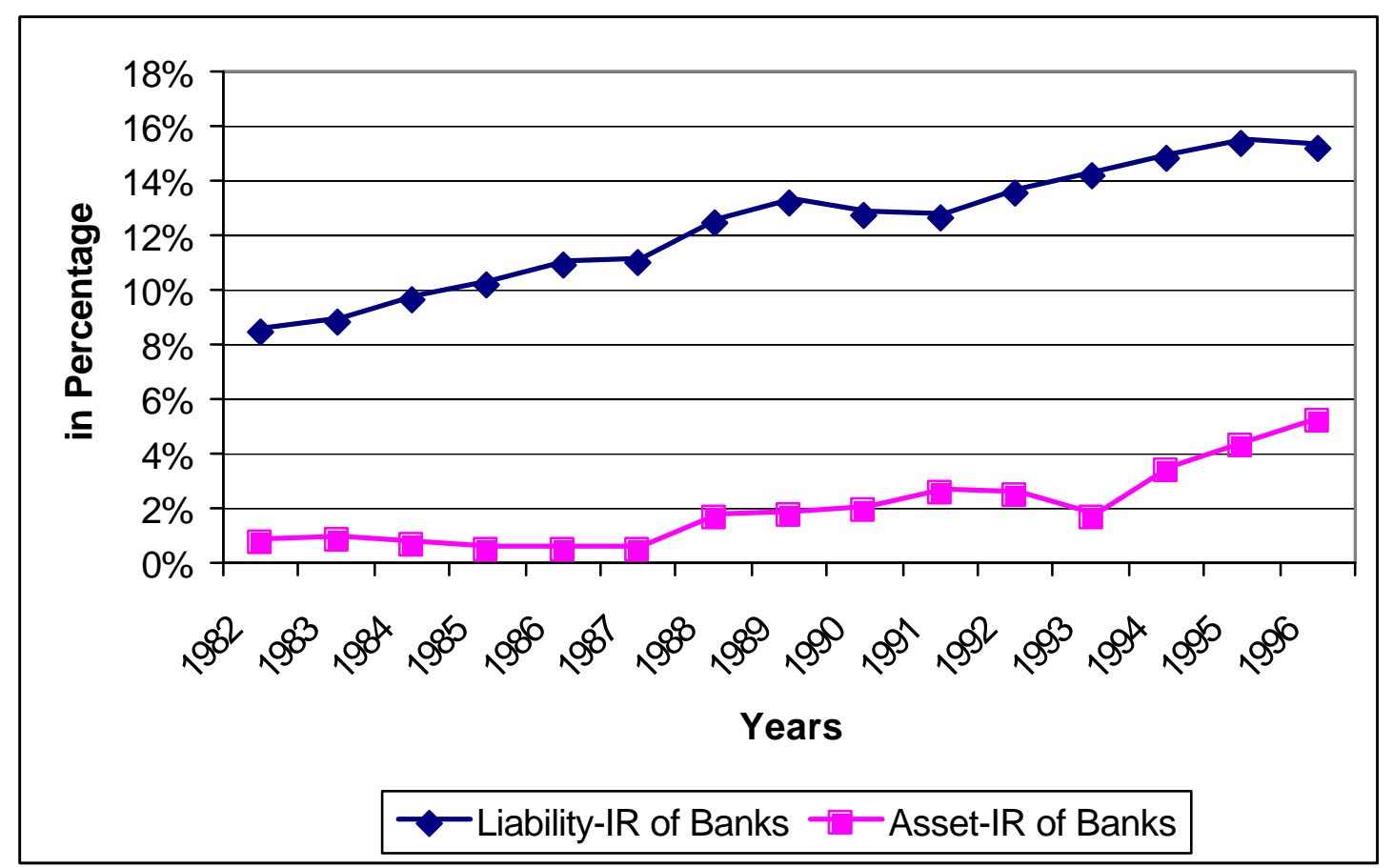

Source: Schmidt/Hackethal/Tyrell (1999)

\section{b) The savings behaviour of households}

One weakness of studies based on flows of funds is the high level of aggregation of the underlying data, which corresponds to the fact that one can only differentiate between sectors and that therefore intra-sectoral financial relationships are not captured. Therefore, microbased studies are of great value as a means of checking the robustness of the results. In the following, we report some results of studies by Börsch-Supan and co-authors ${ }^{37}$ that describe the savings behaviour and portfolio choices of German households in the 1980s and the early 1990s based on a synthetic panel of four cross sections of the German Income and Expenditure Survey.

These studies show, first of all, that financial savings rates in Germany have been fairly high by international standards despite the fact that Germany has one of the most generous public pension and health insurance systems in the world. The authors call this the "German savings 
puzzle". Second, home ownership rates are low by international standards. Third, German private households are not highly indebted. Consumer credit levels are low compared to the Anglo-Saxon countries and it was only recently that debt financing of real estate increased to nearly two-thirds of the sales value of housing. Fourth, non-financial assets, i.e. mainly real estate wealth, represent roughly two-thirds of the total wealth of households. In 1993, financial portfolios were still dominated by relatively safe assets, i.e. checking and savings accounts and domestic bonds issued either by the government or by banks, and by illiquid assets, mainly life insurance policies. Only $12 \%$ of the population of western Germany held stocks directly, whereas more than $60 \%$ of the households held a life insurance policy and one third had domestic bonds in their portfolio. See Table 2 for some figures. Thus, in general these studies confirm the results of the study by Schmidt, Hackethal and Tyrell (1999) based on flow-of-funds statistics, namely that conventional financial intermediaries and in particular banks played the dominant role as mobilisers of household savings. Especially, if one compares the portfolio structure of German households to the portfolio structure of households in the United States and in the United Kingdom - as was done in the recent book by Guiso, Haliassos and Jappelli (2002) - then large differences will become apparent: Households in the Anglo-Saxon countries have higher direct and indirect stockholdings, and the fraction of total risky (financial) assets in their portfolios is usually higher (see the dountry chapters in Guiso, Haliassos and Jappelli (2002).

\footnotetext{
37 See Börsch-Supan/Eymann (2002) and Börsch-Supan et al. (1999, 2000a, 2000b) for details and further references. The source data are taken from the "Einkommens- und Verbrauchsstichproben" (EVS) 1978, 1983, 1988 and 1993. A similar study, using national accounts data, was provided by the Deutsche Bundesbank (1999). Neither data sets provide an unbiased estimate of households' asset holdings. The national accounts exclude the holding of foreign assets and the EVS the top 3 percent of German households per income. Because both data sets reflect similar trends, the biases do not seem to be crucial.
} 
Table 2: Breakdown of Portfolios held by German Households

\begin{tabular}{|c|c|c|c|c|c|c|c|}
\hline & \multicolumn{3}{|c|}{$\begin{array}{l}\text { Asset shares according to } \\
\text { survey data }\end{array}$} & \multicolumn{2}{|c|}{$\begin{array}{l}\text { Ownership } \\
\text { Rates }\end{array}$} & \multirow[b]{2}{*}{1988} & \multirow[b]{2}{*}{1993} \\
\hline & 1983 & 1988 & 1993 & 1978 & 1983 & & \\
\hline & (West) & (West) & (Unified) & (West) & (West) & (West) & (Unified) \\
\hline \multicolumn{8}{|l|}{ Financial assets } \\
\hline Checking and savings acc's & 26.9 & 26.4 & 24.1 & 91.2 & 90.6 & 84.7 & 99.4 \\
\hline Government bonds & 3.2 & 2.4 & 4.7 & 6.3 & 6.4 & 4.8 & 10.5 \\
\hline Other bonds & 11.3 & 11.7 & 15.2 & 16.8 & 21.3 & 22.6 & 30.8 \\
\hline Stocks & 3.8 & 4.7 & 4.3 & 10.0 & 9.7 & 11.4 & 10.0 \\
\hline $\begin{array}{l}\text { Mutual funds and managed } \\
\text { investment accounts }\end{array}$ & 1.5 & 2.2 & 4.7 & 3.8 & 3.3 & 4.7 & 12.9 \\
\hline Life insurance contracts & 36.3 & 39.1 & 29.1 & 69.9 & 67.2 & 64.6 & \\
\hline $\begin{array}{l}\text { Building society savings } \\
\text { contracts }\end{array}$ & 13.1 & 9.9 & 7.2 & 37.1 & 40.5 & 38.7 & 40.2 \\
\hline Other financial assets & 4.0 & 3.5 & 10.7 & n.a & 5.8 & 5.3 & 21.8 \\
\hline Total financial assets & 19.7 & 20.9 & 28.0 & 96.5 & 96.7 & 94.1 & 99.6 \\
\hline $\begin{array}{l}\text { Fraction of "clearly safe" } \\
\text { financial assets }\end{array}$ & 26.9 & 26.4 & 24.1 & 91.2 & 90.6 & 84.7 & 99.4 \\
\hline $\begin{array}{l}\text { Fraction of "fairly safe" } \\
\text { financial assets }\end{array}$ & 66.8 & 64.9 & 64.1 & 80.9 & 81.3 & 78.2 & 82.6 \\
\hline $\begin{array}{l}\text { Fraction of "risky" financial } \\
\text { assets }\end{array}$ & 6.3 & 8.8 & 11.8 & 14.1 & 13.7 & 17.9 & 25.1 \\
\hline \multicolumn{8}{|l|}{ Non-financial assets } \\
\hline Total real estate & 81.2 & 80.2 & 73.4 & 43.3 & 46.0 & 47.4 & 45.8 \\
\hline $\begin{array}{l}\text { Total "risky" } \\
\text { assets="risky" } \\
\text { financial assets }\end{array}$ & 6.3 & 8.8 & 11.8 & n.a & 17.8 & n.a & n.a \\
\hline \multicolumn{8}{|l|}{ Debt } \\
\hline $\begin{array}{l}\text { Mortgage and real estate } \\
\text { debt }\end{array}$ & 92.4 & 91.4 & 90.2 & 24.1 & 26.2 & 25.0 & 23.5 \\
\hline Consumer credit & 7.6 & 8.7 & 9.8 & 14.5 & 17.3 & 19.1 & 21.8 \\
\hline $\begin{array}{l}\text { Consumer credit in \% of } \\
\text { total net wealth(used as } \\
\text { correction term) }\end{array}$ & 1.0 & 1.1 & 1.4 & & & & \\
\hline Total debt & 12.5 & 12.6 & 14.5 & 34.9 & 38.7 & 38.6 & 39.4 \\
\hline
\end{tabular}

Source: Börsch-Supan /Eymann, 2002

\section{c) Financing patterns of non-financial firms}

The fact that private households, as surplus units, invest their funds mainly with banks and insurance companies and that banks use a large fraction of these funds for loans to business should be reflected in the financing patterns of firms. For Germany, one would expect to find that bank loans make up a large proportion of the financing of firms. However, in a series of influential papers, Mayer $(1988,1990)$ and Corbett/Jenkinson $(1996,1997)$ investigated how firms in a number of different industrialised countries obtained funds and financed invest- 
ments. Their general finding was that in all countries covered in their studies external financing was unimportant and, moreover, that bank financing played a particularly unspectacular role in the case of Germany, a country which has always been regarded as having a bankbased financial system. The fraction of financing through bank loans was found to amount to only 11 percent in Germany, as against 14 percent in the UK, a country generally regarded as having a capital market-based financial system.

The Mayer and Corbett/Jenkinson studies have been replicated and essentially confirmed by a number of authors, including Edwards/Fisher (1994) for the case of Germany. Edwards/ Fischer come to the conclusion that "the lack of any evidence that the bank loans are more important in Germany (compared to other countries, especially to Anglo-Saxon countries) casts a great deal of doubt on one of the basic components of the conventional view of the German system of investment finance" (p. 69).

In fact, these results, including those published by Edwards/Fischer for Germany, appear to have become the new "conventional view". This finding, which is widely quoted in the literature, can only be regarded as a puzzle. ${ }^{38}$ Which type of conventional wisdom seems more in line with reality? Hackethal/Schmidt (2000/2003) attempt to resolve this puzzle by showing that the result obtained by Mayer/Corbett/Jenkinson and others stems from a seemingly innocuous assumption in their methodology. Mayer et al. assume that all financing that flows from one type of source, such as the funds flowing from the banking sector to the nonfinancial sector, are first used to fund the reverse flow of the same type, such as debt repayment from corporations to banks. By implication, it is assumed that only what remains after this netting is used for investment purposes. If computations are made on this basis, bank loans that are taken out by one company explicitly for the purpose of financing investments are offset by the debt repayments made by another company, which in preceding periods undertook investments that were financed with bank loans. In a hypothetical situation involving zero growth and in which investments are financed exclusively with bank loans, which must of course be paid back in subsequent periods, the method developed by Mayer et al. shows that the contribution of bank financing equals $0 \%$. Since internally generated finance is the only source of funds for which there is no corresponding use of funds, this method suggests that internally generated funds are invariably used to finance investments. As a

\footnotetext{
38 A collection of references to the work of Mayer and Corbett/Jenkinson, including those whose authors call these findings a puzzle, can be found in Hackethal/Schmidt (2003)
} 
result, they seem to play an overwhelming, and de facto almost exclusive, role in financing corporate investment in every country.

With the same basic intention as Mayer et al., though without employing their problematic assumption, and using the same type of raw data, Hackethal/Schmidt (2003) developed an alternative design to measure the extent to which investment is financed with funds from different sources. Instead of arbitrarily allocating inflows of funds from individual sources to certain outflows and then offsetting the outflows against the seemingly corresponding inflows, they reconstruct gross financial flows, without specifying ex ante how any of the inflowing funds are used. Table 3 show the results for Germany, Japan and the US.

Especially the case of Germany is of interest here. The results reported in Table 3 show that German banks provide a far larger share of external corporate financing than American banks, whereas securities financing, which is behind NBFI financing, is virtually insignificant. In addition, Hackethal/Schmidt (2003) find that, in contrast to the "new conventional wisdom", bank finance is nearly as important as internal finance in Germany, which is clearly not the case in the US. The overall picture of financing patterns which emerges from their data is consistent with the results of various studies using balance sheet data to analyse and compare national financing patterns. ${ }^{39}$ Moreover, it is also in line with the other findings reported in this chapter which indicate that banks played a strong role as providers of business finance at least until the mid-1990s.

\footnotetext{
39 An overview of these studies is contained in Schmidt/Tyrell (1997). See also Sauvé/Scheuer (1999) for a detailed and comprehensive analysis of corporate finance in Germany and France based on balance sheet data from the Deutsche Bundesbank and the Banque de France.
} 
Table 3: Financing patterns of German, Japanese and American companies

\begin{tabular}{lllllll|l}
\hline Country & Sector & '70-'74 & '75-'79 & '80-'84 & '85-'89 & '90-'96 & '70-'96 \\
\hline \multirow{4}{*}{ U.S. } & Percentages of the & volume & of & long-term & external corporate & finance & \\
& Banks & 0.51 & 0.49 & 0.49 & 0.46 & 0.36 & 0.44 \\
& NBFIs & 0.36 & 0.39 & 0.40 & 0.41 & 0.49 & 0.42 \\
& Households & 0.12 & 0.11 & 0.07 & 0.07 & 0.09 & 0.09 \\
& Foreign & 0.01 & 0.02 & 0.04 & 0.06 & 0.06 & 0.04 \\
& countries/State & & & & & & \\
& Securities & 0.42 & 0.42 & 0.41 & 0.45 & 0.48 & 0.45 \\
Germany & Banks & 0.80 & 0.82 & 0.84 & 0.82 & 0.83 & 0.82 \\
& NBFIs & 0.14 & 0.14 & 0.12 & 0.13 & 0.11 & 0.12 \\
& Households & 0.04 & 0.03 & 0.03 & 0.04 & 0.04 & 0.04 \\
& Foreign & 0.02 & 0.01 & 0.01 & 0.02 & 0.03 & 0.02 \\
& countries/State & & & & & & \\
& Securities & 0.12 & 0.09 & 0.08 & 0.11 & 0.13 & 0.12 \\
& Banks & 0.95 & 0.95 & 0.95 & 0.91 & 0.92 & 0.93 \\
\multirow{5}{*}{ Japan } & NBFIs & 0.02 & 0.02 & 0.03 & 0.06 & 0.06 & 0.05 \\
& Households & 0.02 & 0.02 & 0.01 & 0.02 & 0.01 & 0.02 \\
& Foreign & 0.01 & 0.00 & 0.01 & 0.00 & 0.01 & 0.01 \\
& countries/State & & & & & & \\
& Securities & 0.10 & 0.10 & 0.10 & 0.15 & 0.16 & 0.13 \\
\hline
\end{tabular}

Source: Hackethal/Schmidt (2000)

\section{d) Risk-sharing, risk allocation, and the German pension system}

An important function of every financial system is risk sharing. It is often argued that financial markets are particularly well suited to perform this function, which Allen/Gale (1995, 1997) call cross-sectional or intratemporal risk sharing, i.e. the diversification and efficient allocation of the risk to wealth or income at a given point in time. Risks associated with holding stocks, bonds or other financial assets constitute an especially important type of risk that individuals face. However, as can be seen from their portfolio structures discussed above, German households were largely shielded from this risk, at least in the mid-1990s. Both the amount of financial assets and the proportions of risky financial assets among total financial assets held by German households were low in comparison to the US and the UK.

But besides risks that exist at given points in time, there is another form of risk, which Allen/Gale call "intertemporal risk". This risk refers to the availability of economic resources at the level of the economy as a whole or to the aggregate value of all assets, and cannot be diversified at a given point of time through trading risky assets. However, it can be averaged 
over time in a way that reduces the impact on individual welfare. One means of achieving this objective is intergenerational risk sharing, through which the risk associated with a given stock of assets is spread across generations at different positions in their life cycles. Another possibility is asset accumulation, which reduces fluctuations in consumption over time.

In a series of papers, Allen/Gale $(1995,1997,2000)$ show that in a bank-based financial system such as the German system, long-lived financial ins titutions, i.e. banks and insurance companies, can achieve intertemporal risk smoothing through asset accumulation. They can accumulate reserves in good times and draw them down in bad times. But this mechanism only functions as long as the financial intermediaries are not subject to substantial competition from financial markets and are not under strong pressure to use relevant market options when they seem attractive. Competition from markets would unravel the intertemporal smoothing provided by financial institutions because in good times individuals as well as financial intermediaries would rather opt out of the banking system and its practice of accumulating reserves, and instead invest in the market to earn a higher return on their respective investment. The more attractive securities markets are as outlets for investment and the more banks are driven by the objective of maximising profit, the more attractive it is for both sides to abandon a system which, de facto, offers protection against intertemporal risk.

The distinction between intertemporal and intratemporal risk reduction provides a framework for examining the role of risk management in the German financial system. It is helpful to recall our description of the German banking sector as one in which not strictly profit-oriented banks play an important role until this day, and in which even the private banks had for a long time been under relatively little pressure to maximise profit or market value; and also our description of Germany's "underdeveloped" stock market system, and our account of household portfolio structures. Using the ideas of Allen/Gale, one can argue that in the bank-based German financial system of the 80 s and early to mid-90s, risk management was mainly achieved through intertemporal risk smoothing performed by financial intermediaries and in particular by banks and savings banks. They were in a position to, and probably did, reduce intertemporal risk by accumulating assets and issuing low-risk liabilities to typical households as depositors. The reverse side of the coin was that cross-sectional risk sharing through markets was less developed, and had to be less developed in order to sustain the system. This may not have been such a high price to pay, since the demand from ho useholds for options to cope with intratemporal risk may have been low due to typical portfolio structures. 
However, in addition to the risks associated with the holding of financial assets, people face many other risks, such as the risk of unemployment, illness, changes in the value of human capital, and changes in retirement income, to name but a few. In this context the German social security system and in particular its pension system are important.

Germany has a payroll tax-based PAYG system (see Börsch-Supan and Schnabel, 1999 for details). It covers almost all employees and provides almost all retirement income within a single system with relatively transparent rules. In 1993, the first pillar of the pension system, the public PAYG-financed pension system, provided on average $85 \%$ of the total retirement income of a two-person household, and at $70 \%$ the replacement rate of the public pension scheme was relatively high.

This design of the traditional German public pension system was consistent with the prevailing system of risk management in Germany. The pension system absorbed one very important class of risk through intergenerational risk sharing. In addition it reduced the demand for cross-sectional or intratemporal risk management in the economy and thus the need for having a highly developed stock market, which, if it existed, might have undermined the system of risk management through asset accumulation. Finally, given the relative generosity of the public pension system there was less of a need to develop institutional investors such as the British or American pension funds and also not much capital which would have flowed into the capital market through these intermediaries. ${ }^{40}$

\section{e) Information production and dissemination}

Another function of a financial system is the production and dissemination of information, and therefore the type of information provision prevailing in the economy under consideration is yet another element by which a given financial system can be characterised. ${ }^{41}$ In marketbased financial systems, accounting and disclosure requirements are typically more geared to providing public information. Moreover, active stock markets and high levels of direct and indirect investment of household wealth in the capital market create incentives for private information production by investors, fund managers and analysts whose information is indirectly made public through the impact of their trading behaviour on stock prices.

\footnotetext{
40 See Tyrell/Schmidt (2001) for a detailed analysis of the interaction of financial systems and pension systems.

41 On the following, see especially Allen/Gale (2000) and Tyrell (2003).
} 
Generally speaking, the demand for public information is relatively low if capital market investment has only a limited importance for household savings and firm financing. In bankbased financial systems, only relatively few companies are listed and there are few institutional investors. Accordingly, there are also few analysts following individual stocks. This seems to have been the case in Germany until the late 1990s. Moreover, at least until that time German accounting and disclosure regulations were not primarily geared towards satisfying the information needs of investors. ${ }^{42}$ One can therefore surmise that both the direct and the indirect provision and dissemination of public information was not well developed.

In contrast, in a bank-based financial system like Germany, banks as the main external providers of finance to firms need a high level of information, including proprietary information that would not be suitable for public disclosure. The greater prevalence of universal banking based on long-term and relatively close relationships between banks and borrowing firms in turn enables banks to acquire considerable amounts of information about the firms they lend to. Shareholdings by banks in large corporations and the specific forms of corporate governance that prevail in Germany provide additional information and opportunities for information acquisition. Therefore, both in terms of how it is generated and how it is used, information is mainly private rather than public in a bank-based financial system. As Elsas and Krahnen report in their contribution to this book, the re is not only ample anecdotal but also hard econometric evidence that this view of information production and dissemination fits the reality of the German financial system well.

\section{f) The control of capital: Corporate governance in Germany}

A financial system can only perform its main function of channelling funds from savers to investors if it offers sufficient assurance to the providers of the funds that they will reap the rewards which have been promised to them. ${ }^{43}$ To the extent that this assurance is not provided by contracts alone, potential financiers will want to monitor and possibly influence managerial decisions. At least they will want to be sure that certain people - or certain mechanisms have assumed this role of monitoring and influencing the activities of the firm and its management on their behalf. This is obviously the case for providers of equity, who have a genuine

\footnotetext{
42 See the chapter on accounting and disclosure by Leutz and Wüstemann in this book for a characterisation and assessment of German accounting and disclosure.

43 This is the starting point for the influential series of papers by La Porta et al. See especially their 1997 article on "legal determinants of external finance".
} 
interest in the proper functioning of corporate governance. Therefore, corporate governance is an essential part of any financial system, as we explained in Section II.1 above.

However, corporate governance encompasses more than investor protection. Considerations similar to those which stand behind the logical link between equity capital and governance also apply to other stakeholders who invest their resources in a firm and whose expectations of later receiving an appropriate return on their investment also depend on not easily contractible decisions at the level of the individual firm. Lenders, especially long-term lenders, are one such group of stakeholders who may also want to play a role in corporate governance; employees, especially those with high skill levels and firm-specific knowledge, are another.

At least by Anglo-Saxon standards, the German corporate governance system has for a long time appeared to be somewhat anomalous. ${ }^{44}$ It has been shaped by a legal tradition that dates back to the 1920s and regards corporations as entities which act not only in the interest of their shareholders, but which also have to serve a multitude of other interests. These views may sound somewhat outdated today, but they have left their traces. Shareholder value, in the strict or radical sense of an exclusive commitment on the part of management to shareholders' interests, is still not part of German business culture, nor is it in line with actual practice or with the legal system.

Thus, the German legislation governing joint stock corporations (Aktiengesellschaften) distinguishes between three "organs" of a corporation: the general shareholders' meeting, the supervisory board, and the management board. The Joint Stock Corporation Act (Aktiengesetz) gives little power to the shareholders' meeting, moderate power to the supervisory board (Aufsichtsrat) and considerable power to the management board (Vorstand). According to the letter of the law, the legal mandate of the management board is to "manage the company under its own responsibility". This wording is generally taken to mean that the Vorstand must act not only in the interests of owners or shareholders, but also to take into account the interests of other stakeholder groups. As Rieckers and Spindler, two legal scholars, explain in their contribution to this book, the law also assigns to the management board, at least implicitly, the task of striking a balance between different interests.

The main function of the supervisory board consists in appointing and monitoring the management board. But the supervisory board does not merely represent shareholders. For the 
typical large Aktiengesellschaft, the law requires "codetermination" at the corporate level. Under this system, the supervisory board is composed of two almost equally powerful groups of members: on the one hand, those who are elected by the general shareholders' meeting and could at least formally be regarded as representing the shareholders; and on the other, the group of labour representatives. This composition of the supervisory board indicates that it would be wrong to assume that the management board were merely required to maximise shareholder value. In reality the situation is even more complicated than the legal procedure for electing the "capital bench" of the supervisory board and the composition of the supervisory board might suggest. In most cases, a majority of votes are cast by banks, exercising proxy voting rights on behalf of the actual shareholders. Accordingly, the majority of those supervisory board members who are elected by the shareholders' meeting can hardly be regarded as genuine representatives of "pure" investors, i.e. of persons or entities that have no relationship with the corporation other than having invested their money and hoping that the share price will appreciate and that dividends will be paid out. Quite apart from the effects of labour representation, the "genuine shareholder representatives" are a minority on the board of almost every big German corporation. Instead, many board members represent shareholders with large blocks of shares, or they come from the management of other big corporations, or they are high-ranking bank employees, or they are former top managers of the same company. In addition, in strictly legal terms, the supervisory board is not entitled to issue orders to the top management. Thus, the composition of the supervisory board and its limited scope for interfering with the actions of the management reflect the fact that the management board is indeed relatively independent, which is congruent with its legal mandate, as referred to above. On the other hand, these same features make it all the more difficult to strictly and effectively monitor the top managers, and moreover to ensure that they act in the interests of shareholders, given that the legal definition of the task of the management is ambiguous.

If one goes back one step further and looks at the ownership structure of German publicly traded corporations, one notices another peculiarity: In the vast majority of cases, there is at least one blockholder that holds 25 percent or more of the shares and thus has the right to veto important decisions at the shareholders' meeting. Most of these blocks are held by other big

\footnotetext{
44 The topic of corporate governance is dealt with extensively in chapters 3 and 4 of this book. Chapter 3 takes an economic perspective, while chapter 4 takes a legal perspective. Therefore, references are kept to a minimum in the present section.
} 
corporations, or by wealthy families. An elaborate network of interlocking participating interests make the corporate governance system even more complicated.

This brief description of the system of corporate structures, corporate governance and corporate ownership would be incomplete if we did not point out that in Germany there was, and still is, no public market for corporate control as a means of disciplining bad management. Public takeover bids have always been extremely rare, and in the few cases in which there has been a hostile takeover, notably the Mannesmann-Vodafone case of 1999/2000, the bids were not inspired by corporate governance considerations. However, this does not imply that there has been no market for control at all. The findings of Jenkinson and Ljungqvist (2001) suggest that this market takes the form of a market for blocks of shares. As they report, this market is active and at times quite hostile to incumbent management.

At first glance, it might appear as if the German corporate governance system were inimical to "small" shareholders and therefore simply bad by international standards. ${ }^{45}$ This assessment is clearly accurate in the sense that shareholders of this type play no active role in the corporate governance system. Moreover, analysis of the German corporate governance system as a whole suggests that their interests may be an important constraint - that they are shareholders who cannot be treated too negligently - but there does not seem to be any mechanism which would ensure that their interests were the dominant concern of those who "govern" the big corporations.

However, one should not throw the baby out with the bathwater. There is no reason to assume that in the past the "purely investing" public fared badly in the normal course of affairs in Germany. The financial rewards for investing in shares of publicly traded corporations have been in line with those earned in other countries. ${ }^{46}$ In addition, if one looks at the German corporate governance system as a whole, one can recognise that the system has been - or at least for a long time it was - quite well adjusted to the apparent requirements and also quite balanced and ultimately also effective. We discuss these attributes in the next section, which shows how the various elements of the German financial system are interrelated.

\footnotetext{
45 This is also the impression which the reader may gain from the statistics quoted in the papers by La Porta et al.

46 It may be interesting to note that, in terms of long-term share price performance, the German stock market despite "structural underdevelopment" - did not underperform other equity markets in the post second world war period and therefore even small investors on the stock market were able to benefit from holding shares. See the comparative analysis of global stock markets by Jorion/Goetzmann (1999) which make the point that "Germany experienced a steep run-up in prices, 6 percent in real terms, over the period 1950 to 1996" (p. 961).
} 


\section{The systemic perspective: Complementarity and consistency}

In concluding this overview of the German financial system, we now use the information concerning its institutional and functional aspects to outline its systemic features. Through the 1970s and 1980s and well into the 1990s, the key elements of the German financial system could be characterised as follows:

- Banks dominated the financial sector.

- Capital markets were relatively unimportant.

- The predominant forms of financing for non-financial firms were internal financing and bank financing.

- Corporate governance was stakeholder-oriented and accorded a limited role to small equity investors.

- Risk management via the stock market in the sense of dealing with intratemporal risk seems to have played less of a role than risk management in the sense of intertemporal risk sharing and risk reduction.

As we hope to demonstrate in this section, the above configuration of elements is consistent, and given that the elements of a financial system are complementary to each other, this apparent consistency indicates that the German financial system as a whole possessed a certain degree of strength.

As we emphasised at the beginning of this section, the following arguments refer mainly to the German financial system as it was a few years ago, leaving aside for the moment the question of whether or not the systemic features have survived the developments of the past few years. Moreover, this section is intentionally one-sided, in the sense that it does not attempt to account for the many reservations and qualifications that could be expressed with regard to our main proposition. We will not qualify each sentence by noting whether the features which we describe as prevailing in the mid-to-late 1990s are still the same today. The following chapters of this book will provide these details and bring the analysis up to the present time; and they will show that at the beginning of the new millennium the overall picture is much less clear than it was seven or even five years ago.

Five to seven years ago, most German banks and especially the important banks were organised and operated as truly universal banks; they provided a wide array of financial services to their clients, in particular to incorporated and unincorporated business firms. Savings rates in Germany had been relatively high and stable, and bank deposits had for a long time remained 
the main vehicle for the accumulation of private financial savings as well as a stable and relatively cheap source of funds for the banking sector. The provision of banking services to the business community was integrated in the sense that internal flows of information seem to have been relatively easy and well-developed. This enabled banks in their main capacity as lenders to benefit from the information they needed in order to entertain close relations with their customers. Bank-client relations conformed at least to a certain extent to the model of relationship lending and even of "house banking". Banks performed various functions for their business clients, including investment banking services, and some banks also held a large number of equity participations in manufacturing, trade and service companies. Nonetheless, the predominant role played by banks was that of lender.

At that time, the stock market and financing via the capital market played only a minor role. In comparison to other countries, Germany's stock market was still largely underdeveloped as an investment opportunity for households as savers and as a source of funding for business. Thus capital markets did not present a significant competitive challenge to banks in their role as collectors of deposits, providers of funding and the dominant type of financial intermediary. Competition from foreign financial intermediaries was also limited, another factor which has contributed to the stable financial position of the German banking sector.

The high rate of intermediation in general and of bank intermediation in particular confirms the impression that the German financial system was clearly bank-dominated until the late 1990s. Apart from insurance companies, non-bank financial intermediaries were still of minor importance. There were, and still are, no pension funds in Germany, and almost all German unit trusts were organised and managed by bank-affiliated institutions. Just as the banks had been able to build up and maintain a strong position in the business of managing private investment, they also were the driving force in shaping the impressive institutional development of the German stock exchange system in its role as a secondary market.

The predominant financing patterns of non-financial companies reflect the strong role of banks. On average, German corporations are characterised by a relatively high level of internal financing and, to the extent that they use external funding, by a heavy dependence on bank loans. Accounting rules that emphasised creditor protection and restricted the distribution of economic profits seem to have contributed to the prevalence of internal financing and bank loan financing. A particularly interesting element of internal financing, and one that was also quite significant in quantitative terms, were pension reserves maintained within the big corporations. 
So far, it appears that at least until the late 1990s, the overall structure of the German financial sector and the dominant patterns of firm financing seem to have been complementary and consistent. Strong banks, which are exposed to fairly limited competitive pressure and cushioned by an ample stock of cheap deposits, are in a relatively good position to act as "partners" to their business clients. They can provide loans of a sufficient size and maturity, and offer a certain degree of liquidity insurance to their clients. They can even play an active role in supporting their customers if the latter get into financial difficulties. In turn, the fact that banks played a strong role in their relationships with their customers reinforced their dominance within the financial sector.

The overall impression of consistency is confirmed when we look again at the corporate governance system for large corporations. As was explained in the last section, this system seems to be biased against the typical small shareholders, and this might appear to be a serious shortcoming. Yet, there is also a positive side to this system: most importantly, the fact that it appears to be - or rather, have been - consistent with the aforementioned other features of the financial system. By law and in practice, power and influence in German corporations is distributed in a way which, at least in principle, is in Ine with the need to protect various types of claims. As we have seen, banks provide a large part of the external financing, and most bank lending is long-term. This type of financing exposes banks to considerable risks, yet their strong position in the corporate governance system would appear to protect them, in their role as lenders, quite effectively and thus reinforces and facilitates the prevailing form of external financing. Similar considerations apply to labour representation, even though the legalistic rigidities of the mandatory codetermination system would seem to be a serious deficiency of the German system. At least until quite recently, labour turnover has been lower in Germany than in other comparable countries (see Hackethal (2000) for empirical support). Employees' willingness to build up firm-specific human capital and to develop a relatively high degree of loyalty to a firm also exposes them to specific dangers and suggests that they would need protection (and might be willing to pay for $\dot{\mathbf{t}}$ in appropriate forms). It would now seem to be generally accepted that the German system of corporate governance - with codetermination at shop floor and corporate levels, with former managers and managers of other firms holding seats on supervisory boards, and with management boards being legally committed to serving broader interests than merely those of the shareholders - has served to safeguard labour's interest in having stable and long-term employment, and thus to encourage employees to think of themselves as the "partners" of their employers, and behave accordingly. 
The German corporate governance system may also be balanced and quite effective. In this "corporatist" system, power and influence are distributed among a relatively small group of active players, who are in a position to be relatively well informed and can therefore monitor management well, at least in principle. The active and influential players represent big shareholders, big business, big management, big banks, and big labour. On the one hand, these influential players represent clearly divergent interests. As the balance of power between the powerful groups might occasionally shift, it is important that management is shielded from the direct influence of the supervisory board. The legal regime of the German Aktiengesellschaft provides this isolation. On the other hand, in spite of their conflicts, the various influential players share a common task and common interests: they must be able to collectively monitor management, and they have a largely similar interest in assuring the stable development of "their" corporations. Thus monitoring and governing can function reasonably well albeit in a sense which is not necessarily in the best interests of the "pure" shareholders.

Under relatively stable economic conditions, corporate governance designed along these lines might have been beneficial for the development and the implementation of long-term strategies and for the competitiveness of German corporations. Business success also tends to benefit investors. Therefore, the consistency of the corporate governance system may ultimately also be the reason why the interests of those shareholders who are not blockholders have not been violated to a large extent, even though the system gives them little opportunity to play an active role. But what may have mattered more, even for the small investors, is that German corporate governance was consistent with the financing patterns which have prevailed at least until quite recently, and thus also with the structure, the role and the functions of the German financial sector. This mutual compatibility may have been a source of strength for the entire system, since its individual elements tend to reinforce each other in the way in which they contribute to the functioning of the entire system.

An interesting and characteristic feature of the German financial system in general is that the role of the profit motive is somewhat limited, an assessment which applies to banks as well as to non-financial corporations. This statement does not mean that German banks and other German corporations are not profit-oriented; to claim any such thing would be to deny the obvious reality. But one can safely assume that strict profit maximisation is not the dominant scheme of things in Germany. For the public sector savings banks group, this results from their legal mandate and structure. The same applies to the cooperative banking group. But it also applied to the big exchange listed corporations because of their internal governance system. In the case of large German corporations, the "softening" of the profit orientation is 
an outgrowth of their governance structure and the strong role of stakeholder groups that are mainly interested in achieving stable growth rather than in maximising profits.

From a systemic perspective, the moderate restrictions to pure profit orientation seem largely compatible with the relatively high level of debt financing and the focus of many German corporations on rather sophisticated technologies which require a high level of human capital in general and firm-specific human capital in particular. In order to attract long-term debt capital and specialised - and thus expropriable - human capital, firms need ways of assuring the providers of these resources that their interests are indeed safeguarded to a certain extent. Thus the financing patterns and the governance structure - and also the human capital endowments - have at least for a long time been well adjusted to one another. ${ }^{47}$

The argument that the main elements of the financial system in Germany are not only complementary to each other, but have also long been consistent is not limited to the three key elements discussed at some length here, i.e. the role of banks in the financial sector, the financing patterns of firms, and the corporate governance system. Indeed, it can easily be extended to other elements of the overall system. ${ }^{48}$ For instance, it would also seem to apply to the way in which corporations accommodate the need to make important strategic changes; to the disclosure and accounting rules, which have traditionally favoured the interests of lenders, management and staff by limiting the amount of financial surplus which is regarded as "distributable profit"; to the basic structure of the bankruptcy law; and to the pension system. 49

We can summarise this section by restating the two main propositions of the entire chapter. The first proposition is that the German financial system has for quite some time been a consistent system of complementary elements. We attempted to show that the values taken on by the various elements were such that the elements supported each other in their respective functions. The second proposition refers to the way in which, in our view, one should bok at financial systems. We tried to demonstrate that it is indeed possible, and may offer important insights, to view a financial system not as a mere collection of elements, but also as a "true" system composed of elements which strongly interact. But we would like to emphasise that complementarity and consistency are not directly observable features of a given financial

\footnotetext{
47 For more details see Schmidt (2001) and Hackethal/Schmidt (2000).

48 For a general account, see Hackethal/Schmidt (2000), and for a formal model Hackethal/Tyrell (1999).

49 These ext ensions are discussed in Hackethal (2000, pp. 296 ff.), Wüstemann (2002), Hackethal/Tyrell (1999) and Tyrell/Schmidt (2001) respectively.
} 
system. Instead, they are the result of an economic interpretation of the observable facts. Moreover, we would certainly acknowledge that others may disagree on both counts: they may question our claim that the German system was largely consistent, and they may question our claim that complementarity and consistency are important features of a financial system.

\section{A brief international comparison and a short outlook}

\section{Comparing financial systems}

As the preceding overview has hopefully demonstrated, the common characterisation of the German financial system as being bank-dominated and as having an insider-control system of corporate governance seems justified - or at least was fully justified in the mid-to-late 1990s. From a systemic point of view, this system is, or at least was, a consistent configuration of complementary elements. This prompts us to ask whether the financial systems of other large industrial countries are similar to or different from Germany's in this respect. We start with a look at large European economies ${ }^{50}$ and then consider the situation in the U.S. and Japan.

The British financial system is the polar opposite to the German system. British banks play a relatively insignificant role as financial intermediaries and as providers of longer term financing to the business sector. For Britain, the intermediation ratios with respect to banks, which were shown for the case of Germany in Charts 1 and 2 above, are consistently lower both on the liability side (in particular, bank deposits by households) and even more so on the asset side of the banks' aggregate balance sheet (in particular, bank financing of non-financial firms). Bank deposits are not a widely used vehicle for household savings, and the level of firm financing by banks is moderate at best, and tends to be short-term. Moreover, bankcustomer relations are typically not close.

Compensating for the fact that banks play only a limited role as financial intermediaries, Britain's NBFIs, especially life insurance and pension funds, play a much stronger role than those in Germany. As British NBFIs tend to invest a large part of their mobilised funds in stocks, it is only to be expected that - in sharp contrast to the German situation - the stock market is also of great importance in the UK. The British stock market, both as a primary and as a secondary market, is well developed in institutional respects and in terms of its economic role. It even tends to play an important role in corporate governance, since hostile takeovers

\footnotetext{
50 We have developed this comparison in a series of papers which are summarised in Schmidt/Hackethal/Tyrell (2002).
} 
are frequent and can, at least in principle, be regarded as a device to force managers into adhering to shareholders' interests.

Thus, the British corporate governance system is in line with these features of the financial sector and with the prevailing mechanisms by which wealth is accumulated and held, and firms are financed. In the UK, it seems to be accepted without question that the overriding and indeed the only task of the management of a firm is to increase the wealth of the shareholders. Bank influence is absent from the governance of corporations, and various legal provisions ensure that banks refrain from getting involved in corporate governance and policies. But there is also no need for them to be active in boardrooms and work-out groups, since the legal system and the short-term nature of their lending serves well enough to protect their interests as lenders. Similar considerations apply to employees. They are relatively well protected by a well functioning labour market, meaning that they can walk away much more easily than their German counterparts, and therefore would, in economic terms, be less willing to bid for the right to have an active role in corporate governance. Employees do not have such a role, and they would also not need to have it. But if they had it, this would be inconsistent with the entire system. This is why there is no reason to have a "difficult" governance system, and it is understandable that the stock market plays such a big role in the financial system as it seems to in the UK.

While it is the polar opposite of the German financial system in terms of how it functions, it is similar to the German system in so far as it also seems to be largely consistent. Moreover, like the German financial system, it is also surprisingly stable in terms of how it operates.

Until the mid-1980s, the French financial system was strongly dependent on the state, and more specifically on the central government having and using a host of instruments which enabled it to actively influence the financial sector. Under the umbrella of strong government guidance, the financial system was extremely bank-dominated, and the French corporate governance system was a peculiar kind of an insider-control system. Until the mid-1980s, there had been a certain "logique" to the French system, and its modus operandi was different from that of either Germany or the United Kingdom. In the course of the 1980s, the French system altered dramatically, and although it was again the French state which introduced these changes and pushed them through, the entire French financial system has become much more market-oriented than it had ever been. The role of banks as intermediaries has declined dramatically over the last 20 years, a development which is reflected in the financing patterns of firms, and of large corporations especially. In their place, the liberalised capital market has 
gained ground. Moreover, the banks have also suffered in their other roles. The financial sector institutions which have taken over much of the former role of the banks are the NBFIs, in particular various types of investment funds.

All in all, one can certainly say that the developments that have taken place in the French financial system have brought it closer to the Anglo-Saxon model of a capital market-oriented financial system. Thus, in stark contrast to both the German bank-based financial system and the British capital market-based system, the French financial system has not been stable. Moreover, although one might have the impression that a simple conversion from one type of financial system to the polar opposite type has occurred, if one looks at the details the situation becomes less clear-cut. In many respects, the French financial system has - at least for a long period - not been a consistent set of complementary elements. As two important examples of inconsistencies, we would point to the French corporate governance system and to the French system of old age pensions. For a very long time - and indeed, this may even still be the case today - these elements of the French system have remained largely similar to what they used to be under the old regime of state-controlled capitalism that prevailed in the 1970s. In other words, the elements of the newly emerging French financial system have also not been consistent, and possibly they are still not consistent today. The combination of farreaching changes and a situation of not yet having settled into a new consistent configuration or a new type of equilibrium may be the reason why, in the recent past, French economists, bankers and politicians have talked so much about a crisis which accompanied the end of "l'exception française" (Pastré).

We would like to conclude this discussion with an even briefer look at other continents. At the turn of the millennium, when the world-wide stock market rally was coming to an end, the American financial system was arguably even more market-oriented than before. Banks had become even less important both in the financial sector and in the financial system at large. Their role as mobilisers of savings and as lenders has steadily decreased in the course of the last 20 years, as can be read off from the intermediation ratios (Hackethal 2001). However, there are also a number of features and events which would seem to contradict the proposition that the American financial system is becoming ever more market-oriented. One of these is the demise of the Glass Steagall Act in 1999 and with it the acceptance of the universal banking model, which could, in our view, strengthen the role of banks. Another is the wave of state regulation and legislation which undermines the functioning of the market for corporate control by creating numerous obstacles to truly hostile takeovers. All in all, therefore, the evidence would seem to be mixed, although no major inconsistencies appear to have emerged. 
The case of Japan is much less ambiguous in this respect. Not long ago, the Japanese financial system was in almost all respects even more bank-dominated than the German system. One piece of evidence to support this claim is the very high rate of intermediation in Japan (Hackethal 2001) during the last decades; another is the fact that banks contribute a high percentage of non-financial firms' external financing, as reported by Sussman (1994) and Hackethal/Schmidt (2000). Hoshi provides a lucid account of the systemic features and the high degree of consistency of the Japanese financial system of a few years ago, and of its corporate governance system in particular. ${ }^{51}$ It may well be that this consistency of the economic and social system, which included many more elements than merely the financial system, was one of the reasons for Japan's enormous economic success in the 1970s and 1980s.

However, this was not to last, it seems. Since the end of the so-called bubble economy, the Japanese financial system has been in a deep and almost permanent crisis which dwarfs that of the French financial system. A series of changes, some of them rather half-hearted, have pushed the Japanese financial system in the direction of the American system, without, however, leading it to a new system which can by now be characterised as consistent and thus as economically attractive.

\section{Caveats and a brief look ahead}

At least in one respect the German financial system is not different from those of other industrialised countries: It has changed a great deal during the last half decade. Before that, it did however differ in a fundamental way from many other financial systems, especially from those of the Anglo-Saxon countries. As we pointed out in section IV 4, the German financial system has at least until quite recently been a largely consistent bank-based system. This section is supposed to add caveats and a short look ahead. We begin with the caveats.

Our proposition that the German financial system was largely consistent, is an assessment which rests on interpretations and ultimately on the personal judgement of its authors. Consistency is not a feature which lends itself to easy measurement. However, our proposition is not purely speculative. Over the past years, we have, often in collaboration with Andreas Hackethal, tried out, modified and extended the ideas of complementarity, consistency and bankorientation, and we found it useful and in accordance with the facts. Moreover, we find support for our ideas in the work of Allen and Gale over an equally long time. So, in this

\footnotetext{
51 See Hoshi (1998). The same picture of systemic coherence is provided, from a more general perspective, in
} 
limited sense, our proposition is "tested and confirmed". Nevertheless, it is not proven in a formal way, and it cannot be proven. This requires a strong caveat.

In classifying the German financial system as having been bank-based or bank-dominated, we use a distinction which also requires a caveat: Such a qualification is only meaningful if there is at least one other type of financial systems and if financial systems can be qualified as conforming to one of these types. There is indeed an alternative, namely that of a capital market-based or capital market-dominated financial system. However, not all financial systems can be classified as belonging to one of these two types. These types are theoretical constructs, and countries' real financial systems conform to them more or less well. Many real financial systems can hardly be classified as being of either of these two types. This fact limits the usefulness of this classification.

What appears like a third caveat is merely a warning of a possible misunderstanding. The recent wave of empirical research into the relationship between financial systems and economic growth seems to suggest that any classification of financial systems should be linked to some operational standard of evaluation. For instance, one might expect "more capital market orientation" or "more bank-dominance" to go hand in hand with higher growth rates. Levine and others investigate this relationship empirically, and their results do not support this expectation. ${ }^{52}$ However, we do not regard these findings as invalidating our classification and detracting from its relevance, since what we regard as an important determinant of growth or welfare is not whether a financial system is bank-based or capital marketbased, but rather whether it is consistent or not. This feature has so far not been tested in empirical studies.

We now turn to predictions, anticipating what will be presented in greater detail in the concluding chapter of this book. While half a decade ago the German financial system still was a largely consistent bank based system, this has changed recently. The worldwide stock market boom and the "new economy bubble" of the late 1990s have also affected the German financial system. Towards the end of the last century, the German financial system seemed to change rapidly and in a fundamental way. It seemed to undergo a "gestalt switch", i.e. to loose its traditional character of being bank-based and to become a capital market-based system. At least the beginnings of such a fundamental transformation were readily observable. However, this process had only started, and it did not continue after the bursting of the stock market 
bubble in early 2000. It is hard to say whether the process was merely delayed or definitely stopped or even reversed. This is again a matter of interpretation. There are theoretical and empirical arguments which speak for each of the three possibilities - delay, termination or reversal. In our view, "the facts" have not given a loud and clear answer to the question of what has happed since 2000. Even at the time at which this book goes to the publisher (May of 2003), this is an open question. All that seems clear to us is that the German financial system has lost its former consistency. As we said before, we assume that the consistency of a financial system, or a good fit of its main elements, creates economic benefits. The converse statement is that inconsistency causes economic problems. This seems to be born out these days. There are several instances of grave contradictions in the financial system, and one can find a number of equally important problems. The stock market has lost its attraction; the famous Neuer Markt, the premier symbol of the transition to the market-based system, is being closed down after loosing its credibility. The big private German banks are in serious trouble, not least because they have lost enormous sums of money in their ventures to become truly modern investment banks. In the business year of 2002, most of them had to show losses for the first time in their history. And while it was a traditional strength of the German financial system that creditworthy businesses can be almost sure to get loans from their banks, there is now the danger of a credit crunch.

A financial system with grave inconsistency is under pressure to restore consistency. A longer period in which such a system fails to restore a proper fit of its elements can even lead to a financial crisis. We do not really expect this to happen. However, we think that something needs to be done quickly and with great resolve to restore consistency and thus also efficiency. In principle, this could be a reversal to the "good old times" of the bank-based system. But for reasons which we do not want to explain here, this option is not realistic. ${ }^{53}$ Instead, we expect the German financial system to return to its path of transition to a capital market-based system. But the path is going to be rough and long.

52 See Levine (1997) and Levine (2002) with further references.

53 See Schmidt, Hackethal and Tyrell (2002) and also chapters 3 and 15 in this volume. 


\section{References}

ALBRECHT, P./SCHRADIN, H. (1999): Struktur der Versicherungswirtschaft, Seminar für Versicherungslehre - University of Cologne, mimeo

AleXANDER V./BOHL, M. (2000): Das Finanzsystem in Deutschland, in: Obst/Hintner: Geld-, Bank- und Börsenwesen, 40 ${ }^{\text {th }}$ edition, Stuttgart, pp. 447-470ALLEN, F./GALE, D. (1995): A Welfare Comparison of Intermediaries and Financial Markets, European Economic Review, 39, pp. 179-209

ALLEN, F./GALE, D. (1997): Financial Markets, Intermediaries and Intertemporal Smoothing, Journal of Political Economy, 105, pp. 523-546

Allen, F./GALE, D. (2000): Comparing Financial System, MIT Press: Cambridge, MA Allen, F./ SANTOMERO, A. (2001): What Do Financial Intermediaries Do? Journal of Banking and Finance, Vol. 25, pp. 271-294

AOKI, M./PATRICK, H. (1994): The Japanese Main Bank System, Oxford University Press: Oxford

AOKI, M. (2001): Toward a Comparative Institutional Analysis, MIT Press: Cambridge, MA BAIN, A.D. (1992): The Economics of the Financial System, 2nd edition, Basil Blackwell: Oxford

BARCA, F. ET AL (2001): The Control of Corporate Europe, Oxford University Press: Oxford BAUMS, T. (1996): Universal Banks and Investment Companies in Germany, in Saunders, A./Walter, I. (eds.): Financial System Design: Universal Banking Considered, Irwin: Homewood, pp. 124-160

BAUMS, T./THEISSEN E. (1999): Banken, bankeigene Kapitalanlagegesellschaften und Aktienemissionen, Zeitschrift für Bankrecht und Bankwirtschaft, Vol.11 No. 3, pp. 125-134 BÖHMER, E. (2001): Corporate Governance in Germany: Institutional background and empirical results, in K. Gugler (ed.): Corporate governance and economic performance, Oxford University Press: Oxford, pp. 96-120

BÖRSCH-SUPAN, A./EYMANN, A. (2002): Household Portfolios in Germany, in L. Guiso et al. (eds.): Household Portfolios, MIT Press: Cambridge, pp. 291-340 
BÖRSCH-SUPAN, A./SCHNABEL, R. (1999): Social Security and Retirement in Germany, in Gruber, J./Wise, D. (eds.): Social Security and Retirement around the World, The University of Chicago Press: Chicago, pp. 135-180

BÖRSCH-SUPAN, A. ET AL (1999): Ersparnisbildung in Deutschland: Messkonzepte und Ergebnisse auf Basis der EVS, Allgemeines Statistisches Archiv, 83, pp. 385-415 BÖRSCH-SUPAN, A. ET AL (2000a): Household Savings in Germany, Beiträge zur angewandten Wirtschaftsforschung No. 577-00, University of Mannheim

BÖRSCH-SuPAN, A. ET AL (2000b): The German Savings Puzzle, Beiträge zur angewandten Wirtschaftsforschung No. 594-00, University of Mannheim

BuCKLE, M./ThOMPSON, J. (1998): The UK Financial System, Theory and Practice, $3^{\text {rd }}$ edition, Manchester University Press: Manchester

BÜSCHGEN, H.E. (1993): Bankbetriebslehre: Bankgeschäfte und Bankmanagement, $4^{\text {th }}$ edition, Gabler: Wiesbaden

CoRBETT, J./JENKInsON, T. (1996): The Financing of Industry, 1970-89: An International Comparison, Journal of the Japanese and International Economies, 10, pp. 71-96

CoRbeTt, J./JEnkinson, T. (1997): How is Investment Financed? A Study of Germany, Japan, the United Kingdom and the United States, The Manchester School, Supplement, pp. 63-93

CRANE, D.B. ET AL (1995): The Global Financial System: A Functional Perspective, Harvard Business School Press: Boston

DAVIS, E.P./STEIL, B. (2001): Institutional Investors, MIT Press: Cambridge, MA

DEUTSCHES AKTIENINSTITUT (2001): DAI-Factbook 2001, Frankfurt/Main

DIAMOND, D. (1984): Financial Intermediation and Delegated Monitoring, Review of Economic Studies, 51, pp. 393-414

DIAMOND, D./RAJAN, R.G. (2001): Liquidity Risk, Liquidity Creation and Financial Fragility, Journal of Political Economy, 109, pp. 287-327

Deutsche Bundesbank (1995): The Monetary Policy of the Bundesbank, Special Publications, Frankfurt/Main

Deutsche BundesBAnK (1996): Banking Statistics, June 1996, Frankfurt/Main 
DeUTSCHE BundeSBANK (1998): Structural Change in the German Capital market in the runup to European monetary union, Monthly Reports, April 1998, pp. 55-69

Deutsche BundesbanK (1999): Changes in Households' Asset Situation Since the Beginning of the Nineties, Monthly Reports, January 1999, pp. 33-50

DEUTSCHE BUNDESBANK (2002): Banking Statistics, May 2002, Frankfurt/Main

DORE, R. (2000): Stock Market Capitalism: Welfare Capitalism, Oxford University Press:

Oxford

EDWARDS, J./FISCHER, K. (1994): Banks, Finance and Investment in Germany, Cambridge University Press: Cambridge (UK)

EuROPEAN CENTRAL BANK (2002): Payment and Securities Settlement Systems in the European Union, Blue Book, Frankfurt/Main

FAUGERE, J.-P./VoISIN, C. (1994): Le système financier français, Nathan: Paris

FERRANDIER, R./KOEN, V. (1994): Marchés de capiteaux et Techniques Financières, 3rd edition, Jouve: Paris

FoHLIN, C. (2000): Relationship Banking, Liquidity, and Investment in the German Industrialization, Journal of Finance, 53, pp. 1737- 1758

FRANKS, J./MAYER, C. (1995): Ownership and Control, in H. Siebert (ed.): Trends in Business Organization: Do Participation and Cooperation Increase Competitiveness?, Mohr: Tübingen, pp. 171-195

FUdENBERG D./TIROLE J. (1991): Game Theory, MIT Press: Cambridge, MA.

GERSCHENKRON, A. (1962): Economic Backwardness in Historical Perspective, Harvard University Press: Cambridge, Mass.

Guiso, L./Haliassos, M./JaPPELLI, T. (2002): Household Portfolios, MIT Press: Cambridge

GURLEY, J./S HAW, E. (1960): Money in a Theory of Finance, Brookings Institution:

Washington D.C.

HACKETHAL, A. (2000): Banken, Unternehmensfinanzierung und Finanzsysteme, Peter Lang: Frankfurt/Main

HACKeTHAL, A. (2001): How Unique are US-Banks? - The Role of Banks in Five Major Financial Systems, Jahrbuch für Nationalökonomie und Statistik, 221, pp. 592-619 
HACKETHAL, A./SCHMIDT, R. H. (2000): Komplementarität und Finanzsysteme, in: Kredit und Kapital, Beiheft 15, Neue finanzielle Arrangements: Märkte im Umbruch

Hackethal, A./Schmidt, R. H. (2003): Financing Patterns: Measurement Concepts and Empirical Results, Working Paper Series: Finance and Accounting, No. 33, University of Frankfurt, revised version

HACKethal, A./Tyrell, M. (1999): Complementarity and Financial Systems - A Theoretical Approach, Working Paper Series: Finance and Accounting, No. 10, University of Frankfurt HARHOFF, D./KÖRTING, T. (1999): Lending Relationships in Germany - Empirical Evidence from Survey Data, Journal of Banking and Finance, 22, pp. 1317-1353

Hartmann-Wendels, T./Pfingsten, A./WEBer, M. (1998): Bankbetriebslehre, Springer: Berlin et al.

HeLlwIG, M. (2000): Die volkswirtschaftliche Bedeutung des Finanzsystems, in:

Obst/Hintner: Geld-, Bank- und Börsenwesen, 40th edition, Stuttgart, pp. 3-37

HICKS, J. (1969): A Theory of Economic History, Clarendon Press: Oxford

HILFERDING, R. (1910): Das Finanzkapital. Eine Studie über die jüngste Entwicklung des Kapitalismus, Wiener Volksbuchhandlung: Vienna (Reprinted Düsseldorf 2001)

Hoshi, T. (1998): Japanese Corporate Governance as a System, in: Hopt, K. et al. (eds.): Comparative Corporate Governance - The State of the Art and Emerging Research, Oxford University Press: Oxford,

Jenkinson, T./LJungQvist, A. P. (2001): The Role of Hostile Stakes in German Corporate Control, Journal of Corporate Finance, 7(4), 397-446

Jorion, P./GoETZMAnN, W. (1999): Global Stock Markets in the Twentieth Century, 54, Journal of Finance, pp. 953-980

KaufMan, G. (1997): The U.S. Financial System, $6^{\text {th }}$ edition, Prentice Hall: Englewood Cliffs, N.J.

KING, R./LEVINE, R. (1993): Finance and Growth: Schumpeter Might be Right, Quarterly Journal of Economics, 108, pp. 717-737

LA PORTA, R./LOPEZ-DE-SiLANES, F./SHLEIFER, A./ViShNY, R. (1998): Law and Finance, Journal of Political Economy, 106, pp. 1113-1155

LAUX, M./PÄSLER, R. (2001): Die deutschen Spezialfonds, Fritz Knapp: Frankfurt/Main 
LEVINE, R. (1997): Financial Development and Economic Growth: Views and Agenda, Journal of Economic Literature, 35, pp. 688-726

LEVINE, R. (2002): Bank-Based or Market-Based Financial Systems: Which is Better? Working Paper, University of Minnesota

MAYER, C. (1988): New Issues in Corporate Finance, European Economic Review, 32, pp.1167-1183

MAYER, C. (1990): Financial Systems, Corporate Finance, and Economic Development, in G. Hubbard (ed.): Asymmetric Information, Corporate Finance, and Investment, University of Chicago Press: Chicago, pp. 307-332

MAYER, C./Sussman, O. (2001): The Assessment: Finance, Law, and Growth, Oxford Review of Economic Policy, 17 (No.4), pp. 457-466

MCKInNON, R. (1973): Money and Capital in Economic Development, Brookings Institutions: Washington, D.C.

MeRton, R. C. (1990): The Financial System and Economic Performance, Journal of Financial Services Research, 4, pp. 263-300

MERTON, R. C. (1995): Financial Innovation and the Management and Regulation of Financial Institutions, 19, pp. 461-482

MERTON, R. C./BODIE, Z. (1995): A Conceptual Framework for Analyzing the Financial Environment, in D.B. Crane et al. (eds.): The Global Financial System: A Functional Perspective, Harvard Business School Press: Boston, pp. 3-32

Milgrom, P./RoberTs, J. (1990): The Economics of Modern Manufacturing: Technology, Strategy, and Organization, American Economic Review, 80, pp. 511-528

Milgrom, P./RoberTs, J. (1995a): Complementarities and Fit: Strategy, Structure, and Organizational Change in Manufacturing, Journal of Accounting and Economics, 19, pp. 179208

Milgrom, P./RoberTs, J. (1995b): Continuous Adjustment and Fundamental Change in Business Strategy and Organization, in H. Siebert (ed.): Trends in Business Organization: Do Participation and Cooperation Increase Competitiveness?, Mohr: Tübingen, pp. 231-259 OBST/HinTNER (2000): Geld-, Bank- und Börsenwesen, von Hagen, J./von Stein, J.H. (eds.), 40th edition, Schäffer Poeschel: Stuttgart 
PAGANO, M./VOLPIN, P. (2001): The Political Economy of Finance, Oxford Review of Economic Policy, 17 (No. 4), pp. 502-519

PAPENFUSS, H. (1999): Beschreibungsmodi für Finanzsysteme, Peter Lang: Frankfurt/Main RAJAN, R.G. (1996): Why Banks Have a Future: Toward a New Theory of Commercial Banking, Journal of Applied Corporate Finance, 8, pp. 114-135

RAJAN, R.G./Zingales, L. (2001): The Great Reversals: Politics of Financial Development in the $20^{\text {th }}$ Century, Working Paper, University of Chicago

RoBInSON, J. (1952): The Generalization of the General Theory, in The Role of Interest and Other Essays, London: Macmillan, pp. 67-142

SAUVÉ, A./SchEUER, M. (1999): Corporate Finance in Germany and France, Deutsche Bundesbank: Frankfurt/Main

SCHMiDT, R.H./HACKETHAL, A./TYRELL, M. (1999): Disintermediation and the Role of Banks in Europe: An International Comparison, Journal of Financial Intermediation, 8, pp. 36-67

SCHMIDT, R.H./HACKETHAL, A./TYRELL, M. (2002): Convergence of Financial Systems in Europe, Schmalenbach Business Review, Special Issue 1, pp. 7-54

SCHMIDT/R.H./TYRELL, M.(1997): Financial Systems, Corporate Finance and Corporate Governance, European Financial Management, 3, pp. 159-187

SCHUMPETER, J. (1911): The Theory of Economic Development, Harvard University Press: Cambridge, MA

SHAW, E. S. (1973): Financial Deepening in Economic Development, Oxford University Press: New York

SÜChting, J./PAUl, S. (1998): BANKMANAGEMENT, $4^{\text {th }}$ edition, Schäffer-Poeschel: Stuttgart SUSSMAN, O. (1994): Investment and Banking: Some International Comparisons, Oxford Review of Economic Policy, Vol.10 (4), pp.79-93

TOPKIS, D. M. (1998): Supermodularity and Complementarity, Princeton University Press: Princeton, N.J.

TYRELL, M. (2003): Kapitalmärkte und Banken - Formen der Informationsverarbeitung als konstitutives Merkmal, Gabler: Wiesbaden

TYRELl, M./S CHMIDT, R. H. (2001): Pension Systems and Financial Systems in Europe: A Comparison from the Point of View of Complementarity, ifo Studien, 47, pp. 469-503 
VERDIER, D. (1999): The Origins of Universal Banking in $19^{\text {th }}$ Century Europe, North America and Australasia, Working Paper, European University Institute, Florence

WINKLER, A. (2001): Wirtschaftswachstum und Finanzsystementwicklung, mimeo WÜSTEMANN, J. (2002): Institutionenökonomik und internationale

Rechnungslegungsordnungen, Mohr: Tübingen 


\section{Working Paper Series: Finance \& Accounting}

No.110: Falko Fecht, On the Stability of Different Financial Systems, June 2003

No.109: Raimond Maurer/Shohreh Valiani, Hedging the Exchange Rate Risk in International Portfolio Diversification: Currency Forwards versus Currency Options, June 2003

No.108: Raimond Maurer/Frank Reiner/Steffen Sebastian, Financial Characteristics of International Real Estate Returns: Evidence from the UK, US, and Germany, May 2003

No.107: Anne d'Arcy/Michiyo Mori/Christine Rossbach, The impact of valuation rules for intangible assets in Japanese and Germanaccounts of listed companies, April 2003

No.106: Andreas Hackethal, German banks - a declining industry?, March 2003

No.105: Ingo E. Tschach, The long term impact of microfinance on income, wages and the sectoral distribution of economic activity, April 2003

No.104: Reinhard H. Schmidt/Marco Weiß, Shareholder vs. Stakeholder: Ökonomische Fragestellungen, January 2003

No.103: Ingo E. Tschach, The Theoretical Derivation of Credit Market Segmentation as the Result of a Free Market Process, March 2003

No.102: Samuel Lee/Nina Moisa/Marco Weiss, Open Source as a Signalling Device An Economic Analysis, March 2003

No.101: Christian Gaber, Bewertung von Fertigerzeugnissen zu Voll- oder Teilkosten? Ansatz von Forderungen zum Nennwert oder Barwert? Eine agencytheoretische Analyse zur zielkongruenten Performancemessung, December 2002

No.100: Oliver Ruß/Günther Gebhardt, Erklärungsfaktoren für den Einsatz von Währungsderivaten bei deutschen Unternehmen - eine empirische LogitAnalyse, August 2002

No.99: ChristianGaber, Gewinnglättung und Steuerung dezentraler Investitionsentscheidungen bei sich gegenseitig ausschließenden Investitionsprojekten, September 2002

No.98: Volker Laux, On the Value of Influence Activities for Capital Budgeting, September 2002

No.97: Gunter Löffler, Avoiding the rating bounce: Why rating agencies are slow to react to new information, June 2002

No.96: Andreas A. Jobst, Collateralized Loan Obligations (CLOs) - A Primer, December 2002

No.95: Günther Gebhardt/Rolf Reichardt/Carsten Wittenbrink, Accounting for Financial Instruments in the Banking Industry, November 2002

No.94: Ulf Herold/Raimond Maurer, Portfolio choice and estimation risk - A comparison of Bayesian approaches to resampled efficiency, June 2002 
No.93: Olivia S. Mitchell/David McCarthy, Annuities for an Ageing World, June 2002

No.92: Ulf Herold/Raimond Maurer, How much foreign stocks? Classical versus Bayesian approaches to asset allocation, June 2002

No.91: Gunter Löffler/Patrick F. Panther/Erik Theissen, Who Knows What When? - The Information Content of Pre-IPO Market Prices, June 2002

No.90: Reinhard Hujer/Sandra Vuletic/Stefan Kokot, The Markov switching ACD model, April 2002

No.89: Markus C. Arnold/Robert M. Gillenkirch, Stock Options as Incentive Contracts and Dividend Policy, April 2002

No.88: Anne d'Arcy /Sonja Grabensberger, The Quality of Neuer Markt Quarterly Reports - an Empirical Investigation, January 2002

No.87A: Reinhard H. Schmidt/Ingo Tschach, Microfinance as a Nexus of Incentives, May 2001

No.87: Reinhard H. Schmidt/Ingo Tschach, Microfinance als ein Geflecht von Anreizproblemen, Dezember 2001 (erscheint in den Schriften des Vereins für Socialpolitik, 2002)

No.86: Ralf Elsas/Yvonne Löffler, Equity Carve-Outs and Corporate Control in Germany, December 2001

No.85: Günther Gebhardt/Stefan Heiden/Holger Daske, Determinants of Capital Market Reactions to Seasoned Equity Offers by German Corporations, December 2001

No.84: Hergen Frerichs/Gunter Löffler, Evaluating credit risk models: A critique and a proposal, October, 2001

No. 83: Ivica Dus/Raimond Maurer, Integrated Asset Liability Modelling for Property Casuality Insurance: A Portfolio Theoretical Approach, October 2001 (erscheint in Handbuch Asset-Liability Management, hrsg. von M. Rudolph u.a.)

No.82: Raimond Maurer/Frank Reiner, International Asset Allocation with Real Estate Securities in a Shortfall-Risk Framework: The Viewpoint of German and US Investors, September 2001

No.81: Helmut Laux, Das Unterinvestitionsproblem beim EVA-Bonussystem, August 2001

No.80: Helmut Laux, Bedingungen der Anreizkompatibilität, Fundierung von Unternehmenszielen und Anreize für deren Umsetzung, July 2001

No. 79: Franklin Allen/Douglas Gale, Banking and Markets, July 2001

No.78: Joachim Grammig/Michael Melvin/Christian Schlag, Price Discovery in International Equity Trading, July 2001

No.77: Joachim Grammig/Reinhard Hujer/Stefan Kokot, Tackling Boundary Effects in Nonparametric Estimation of Intra-Day Liquidity Measures, July 2001

No.76: Angelika Esser / Christian Schlag, A Note on Forward and Backward Partial Differential Equations for Derivative Contracts with Forwards as Underlyings, June 2001 
No.75: Reinhard H. Schmidt/Marcel Tyrell/Andreas Hackethal, The Convergence of Financial Systems in Europe, May 2001 (erscheint in: Schmalenbach Business Review, 2002)

No.74: Ulf Herold, Structural positions and risk budgeting - Quantifying the impact of structural postions and deriving implications for active portfolio management, May 2001

No.73: Jens Wüstemann, Mängel bei der Abschlußprüfung: Tatsachenberichte und Analyse aus betriebswirtschaftlicher Sicht, April 2001 (erschienen in: „Der Wirtschaftsprüfer als Element der Corporate Governance“, Zentrum für Europäisches Wirtschaftsrecht, Bonn 2001, S. 25-60)

No.72: Reinhard H. Schmidt, The Future of Banking in Europe, March 2001(erscheint in Kapitalmarkt und Portfolio Management, 2002)

No.71: Michael H. Grote/Britta Klagge, Wie global sind Japans Banken? Die Veränderung institutioneller Bedingungen und ihre Auswirkungen auf die internationale Präsenz japanischer Kreditinstitute, April 2001

No.70: Stefan Feinendegen/Eric Nowak, Publizitätspflichten börsennotierter Aktiengesellschaften im Spannungsfeld zwischen Regelberichterstattung und Ad-hoc-Publizität - Überlegungen zu einer gesetzeskonformen und kapitalmarktorientierten Umsetzung, März 2001 (erscheint in: Die Betriebswirtschaft)

No.69: Martin F. Grace/Robert W. Klein/Paul R. Kleindorfer, The Demand for Homeowners Insurance with Bundled Catastrophe Coverages, March 2001

No.68: Raimond Maurer/Martin Pitzer/Steffen Sebastian, Konstruktion transaktions-basierter Immobilienindizes: Theoretische Grundlagen und empirische Umsetzung für den Wohnungsmarkt in Paris, Februar 2001

No.67: Gyöngyi Bugár/Raimond Maurer, International Equity Portfolios and Currency Hedging: The Viewpoint of German and Hungarian Investors, February 2001 (erscheint in. ASTIN-Bulletin)

No.66: Rainer Brosch, Portfolio-aspects in real options management, February 2001

No.65a: Marcel Tyrell/Reinhard H. Schmidt, Pension Systems and Financial Systems in Europe:A Comparison from the Point of View of Complementarity, July 2001

No.65: Marcel Tyrell/Reinhard H. Schmidt, Pensions- und Finanzsysteme in Europa: Ein Vergleich unter dem Gesichtspunkt der Komplementarität, Februar 2001 (erschienen in gekürzter Fassung in: „Private Versicherung und Soziale Sicherung“, Festschrift zum 60. Geburtstag von Prof. Dr. Dr. h.c. Roland Eisen, hrsg. von H.-C. Mager, H. Schäfer, K. Schrüfer, Metropolis: Marburg),

No.64: Jutta Dönges/Frank Heinemann, Competition for Order Flow as a Coordination Game, January 2001

No.63: Eric Nowak/Alexandra Gropp, Ist der Ablauf der Lock- up-Frist bei Neuemissionen ein kursrelevantes Ereignis, Dezember 2000 (erschienen in Zeitschrift für betriebswirtschaftliche Forschung, Februar 2002)

No.62: Ulrich Kaiser/Andrea Szczesny, Einfache ökonometrische Verfahren für die Kreditrisikomessung: Verweildauermodelle, Dezember 2000 
No.61: Ulrich Kaiser/Andrea Szczesny, Einfache ökonometrische Verfahren für die Kreditrisikomessung: Logit- und Probit-Modelle, Dezember 2000

No.60: Andreas Hackethal, How Unique Are US Banks? - The Role of Banks in Five Major Financial Systems, , December 2000 (erschienen in: Zeitschrift für Nationalökonomie und Statistik, Vol. 221, S. 592-619)

No.59: Rolf Elgeti/Raimond Maurer, Zur Quantifizierung der Risikoprämien deutscher Versicherungsaktien im Kontext eines Multifaktorenmodells, Oktober 2000 (erschienen in: Zeitschrift für die gesamte Versicherungswissenschaft 4/2000, S. 577- 603.)

No.58: Harald A. Benink/Reinhard H. Schmidt, Towards a Regulatory Agenda for Banking in Europe, September 2000 (erschienen in: Research in Financial Services-Bank Crises: Causes, Analysis and Prevention, Vol.12, JAI PressElsevier Science, hrsg. von George G. Kaufman, 2000)

No.57: Thomas G. Stephan/Raimond Maurer/Martin Dürr, A Multiple Factor Model for European Stocks, September 2000

No.56: Martin Nell/Andreas Richter, Catastrophe Index-Linked Securities and Reinsurance as Substituties, August 2000

No.55: Four short papers on Development Finance, August 2000

Reinhard H. Schmidt, Entwicklungsfinanzierung; (erschienen in: Handwörterbuch des Bank- und Finanzwesens, 3. Aufl., hrsg. von Wolfgang Gerke und Manfred Steiner, Stuttgart: Schäffer-Poeschel, 2001)

Reinhard H. Schmidt, Banking Regulation contra Microfinance; (erschienen in: Savings and Development, Vol. 24 (2000), S.111-121.)

Ingo Tschach, The Impact of Inflation on Long-Term Housing Loans;

Eva Terberger-Stoy/Marcel Tyrell, Joseph E. Stiglitz (erschienen in: Entwicklung und Zusammenarbeit, 41. Jahrgang (2000), S. 46-49)

No.54: Raimond Maurer/Thomas G. Stephan, Vermögensanlagevorschriften für deutsche Versicherungsunternehmen: Status Quo und finanzwirtschaftliche Bewertungen, Juli 2000 (erschienen in: Handbuch Spezialfonds (hrsg. von J.M. Kleeberg und C. Schlenger), Bad Soden 2000, S. 143-176.),

No.53: Joachim Grammig/Reinhard Hujer/Stefan Kokot, Bias-free Nonparametric Estimation of Intra-Day Trade Activity Measures, June 2000

No.52: Raimond Maurer / Steffen Sebastian / Thomas G. Stephan, Immobilienindizes im Portfolio-Management, Mai 2000 (erscheint in Deutscher Aktuarverein (Hrsg.): Investmentmodelle für das Asset-Liability-Modelling von Versicherungsunternehmen, 2002)

No.51: Raimond Maurer / Steffen Sebastian, Inflation Risk Analysis of European Real Estate Securities, Mai 2000 (erscheint in: Journal of Real Estate Research, 2002)

No.50: Andreas Hackethal / Reinhard H. Schmidt, Finanzsysteme und Komplementarität, April 2000 ( erschienen in: Kredit und Kapital, Beiheft 15 "Neue finanzielle Arrangements: Märkte im Umbruch", 2000, S. 53-102) 
No.49: Mark Wahrenburg/ Susanne Niethen, Vergleichende Analyse alternativer Kreditrisikomodelle, April 2000 (erschienen in: Kredit und Kapital, Heft 2, 2000)

No.48: Christian Leuz, IAS versus US GAAP: A "New Market" Based Comparsion, January 2000

No.47: Ralf Elsas/ Mahmoud El-Shaer/ Erik Theissen, Beta and Returns Revisited Evidence from the German Stock Market, December 1999

No.46: Michael H. Grote/Sofia Harrschar-Ehrnborg/Vivien Lo, Technologies and Proximities: Frankfurt's New Role in the European Financial Centre System, December 1999

No.45: Reinhard H. Schmidt/Adalbert Winkler, Building Financial Institutions Developing Countries, November 1999 ( erschienen in: "Journal für Entwicklungspolitik", XVI/3, 2000, S. 329-346)

No.44: Konstantin Korolev/Kai D. Leifert/ Heinrich Rommelfanger, Arbitragetheorie bei vagen Erwartungen der Marktteilnehmer, November 1999

No.43: Reinhard H. Schmidt/Stefanie Grohs, Angleichung der Unternehmensverfassung in Europa -Ein Forschungsprogramm, November 1999 (erschienen in: Systembildung und Systemlücken in Kerngebieten des Europäischen Privatrechts, hrsg. von Stefan Grundmann, Tübingen: Mohr Siebeck, 2000, S. 146-188)

No.42: Konstantin Kovolev/Kai D. Leifert/ Heinrich Rommelfanger, Optionspreistheorie bei vagen Daten, Oktober 1999

No.41: Christian Leuz/Robert E. Verrecchia, The Economic Consequences of Increased Disclosure (erscheint in: Journal of Accounting Research, Supplement 2000), June 2000

No.40: Christian Leuz, The Development of Voluntary Cash Flow Statements in Germany and the Influence of International Reporting Standards, July 1999 (erschienen in: Schmalenbach Business Review, Vol. 52 (2), April, 2000, S. 182-207.)

No.39: Ulrike Stefani, Quasirenten, Prüferwechsel und rationale Adressaten, Juni 1999

No.38: Michael Belledin/Christian Schlag, An Empirical Comparison of Alternative Stochastic Volatility Models, June 1999

No.37: Jens Wüstemann, Internationale Rechnungslegungsnormen und neue Institutionenökonomik, Mai 1999

No.36: Robert Gillenkirch/Matthias M. Schabel, Die Bedeutung der Periodenerfolgsrechnung für die Investitionssteuerung - Der Fall ungleicher Zeitpräferenzen, April 1999 (die überarbeitete Fassung "Investitionssteuerung, Motivation und Periodenerfolgsrechnung bei ungleichen Zeitpräferenzen" erscheint voraussichtlich 2001 in der ZfbF)

No.35: Reinhard H. Schmidt, Differences between Financial Systems in Europe: Consequences for EMU, April 1999 (erschienen in "The Monetary Transmission Mecha nism: Recent Developments and Lessous for Europe", hrsg. v. Deutsche Bundesbank, Houndsmill (UK), 2001, S. 208-240) 
No.34: Theodor Baums/Erik Theissen, Banken, bankeigene

Kapitalanlagegesellschaften und Aktienemissionen, März 1999 (erschienen in:

Zeitschrift für Bankrecht und Bankwirtschaft, 11 (1999), Heft 3, S. 125-134)

No.33: Andreas Hackethal/Reinhard H. Schmidt, Financing Patterns: Measurement Concepts and Empirical Results, May 2000

No.32: Michael H. Haid/Eric Nowak, Executive compensation and the susceptibility of firms to hostile takeovers - An empirical investigation of the U.S. oil industry, March 1999

No.31: Reinhard H. Schmidt/Jens Maßmann, Drei Mißverständnisse zum Thema "Shareholder Value", Februar 1999 (erschienen in Kumar/ Osterloh/ Schreyö gg (Hrsg.):Unternehmensethik und die Transformation des Wettbewerbs, Festschrift für Professor Dr. Dr. h. c. Horst Steinmann zum 65. Geburtstag,1999, SchäfferPoeschel Verlag Stuttgart, S.125-157 )

No.30: Eberhard Feess/Michael Schieble, Credit Scoring and Incentives for Loan Officers in a Principal Agent Model, January 1999

No.29: Joachim Grammig/Dirk Schiereck/Erik Theissen, Informationsbasierter Aktienhandel über IBIS, Januar 1999 (erscheint in überarbeiteter Fassung in: Zeitschrift für betriebswirtschaftlicher Forschung)

No.28: Ralf Ewert/Eberhard Feess/Martin Nell, Auditor Liability Rules under Imperfect Information and Costly Litigation - The Welfare Increasing Effect of Liability Insurance, January 1999 (erschienen in European Accounting Review genauer!))

No.27: Reinhard H. Schmidt/Gerald Spindler, Path Dependence, Corporate Governance and Complementarity, March 2000 (erscheint in: Jeffrey Gordon \& Mark Roe, eds.: Convergence and Rersistence of Corporate Governance Systems, University of Chicago Press, 2001)

No.26: Thorsten Freihube/Carl-Heinrich Kehr/Jan P. Krahnen/Erik Theissen, Was leisten Kursmakler? Eine empirische Untersuchung am Beispiel der Frankfurter Wertpapierbörse, Dezember 1998 (erschienen in: Kredit und Kapital, 32(1999), Heft3, S. 426-460.

No. 25: Jens Maßmann/Reinhard H. Schmidt, Recht, internationale Unternehmensstrategien und Standortwettbewerb, December 1998 (erschienen in: Jahrbuch für Neue Politische Ökonomie, Band 18, hrsg. von K.-E. Schenk u.a., Tübingen 2000, S. 169-204)

No. 24: Eberhard Feess/Martin Nell, The Manager and the Auditor in a Double Moral Hazard Setting: Efficiency through Contingent Fees and Insurance Contracts, December 1998

No. 23: Carl-Heinrich Kehr/Jan P. Krahnen/Erik Theissen, The Anatomy of a Call Market: Evidence from Germany, December 1998

No. 22: Christian K. Muus, Non-voting shares in France: An empirical analysis of the voting premium, December 1998

No. 21: Christian Leuz, Voluntary Disclosure of Cash Flow Statements and Segment Data in Germany, September 1998 
No. 20: Anne D`Arcy, The Degree of Determination of National Accounting Systems An Empirical Investigation, September 1998

No. 19: Helmut Laux, Marktwertmaximierung und CAPM im Ein- und MehrperiodenFall, September 1998 (erschienen in Unternehmens führung, Ethik und Umwelt, Festschrift zum 65. Geburtstag von Hartmut Kreikebaum, hrsg. von Gerd-Rainer Wagner, Wiesbaden 1999, S. 226-251)

No. 18: Joachim Grammig/Reinhard Hujer/Stefan Kokot/Kai-Oliver Maurer, Ökonometrische Modellierung von Transaktionsintensitäten auf Finanzmärkten; Eine Anwendung von Autoregressive Conditional Duration Modellen auf die IPO der Deutschen Telekom, August 1998

No. 17: Hanne Böckem, An Investigation into the Capital Market Reaction on Accounting Standards Enforcement, July 1998

No. 16: Erik Theissen, Der Neue Markt: Eine Bestandsaufnahme, April 1998 (erschienen in: Zeitschrift für Wirtschafts- und Sozialwissenschaften, Heft 4/98, S. 623-652)

No. 15: Jan Pieter Krahnen, Finanzierungstheorie: Ein selektiver Überblick, April 1998 (englische Fassung erschienen in "Gutenberg Centennial", hrsg. von Horst Albach, Berlin, 2000)

No. 14: Erik Theissen, Liquiditätsmessung auf experimentellen Aktienmärkten, April 1998 (erschienen in: Kredit und Kapital, 32(1999), Heft 2, S. 225-264)

No. 13: Reinhard H. Schmidt, Erich Gutenberg und die Theorie der Unternehmung, February 1998 (englische Fassung erschienen in "Theory of the Firm", hrsg. von Horst Albach u.a., Berlin 2000, S. 3-39)

No. 12: Adalbert Winkler, Financial Development, Economic Growth and Corporate Governance, February 1998 (erschienen in: Asian Financial Markets, hrsg. von Lukas Menkhoff/Beate Reszat, Baden-Baden 1998, S. 15-44)

No. 11: Andreas R. Hackethal/Marcel Tyrell, Complementarity and Financial Systems - A Theoretical Approach, December 1998

No. 10: Reinhard H. Schmidt/Andreas Hackethal/Marcel Tyrell, Disintermediation and the Role of Banks in Europe: An International Comparison, January 1998 (erschienen in: Journal of Financial Intermediation, Vol. 8, 1999, S.37-67)

No. 9: $\quad$ Stefan Heiden/Günther Gebhardt/Irmelin Burkhardt, Einflußfaktoren für Kursreaktionen auf die Ankündigung von Kapitalerhöhungen deutscher Aktiengesellschaften, December 1997

No. 8: $\quad$ Martin Nell, Garantien als Signale für die Produktqualität?, November 1997 (erscheint in: Zeitschrift für betriebswirtschaftliche Forschung)

No. 7: $\quad$ Robert M. Gillenkirch, Anreizwirkungen und Bewertung von Erfolgsbeteiligungen im Portefeuillemanagement, November 1997 (erschienen in: ZfB, Sonderheft Finanzmanagement 1999)

No. 6: Reinhard H. Schmidt/C. -P. Zeitinger, Critical Issues in Microbusiness Finance and the Role of Donors, October 1997 (erschienen in: Strategic Issues in Microfinance, ed. by Kimenyi/Wieland/Von Pischke, Averbury, UK, 1998, S. 27-51) 
No. 5: Erik Theissen/Mario Greifzu, Performance deutscher Rentenfonds, September 1997 (erschienen in: Zeitschrift für betriebswirtschaftliche Forschung, 50. Jg., 1998, S. 436-461)

No. 4: Jan Pieter Krahnen/Martin Weber, Marketmaking in the Laboratory: Does Competition Matter?, September 1997

No. 3: Reinhard H. Schmidt, Corporate Governance: The Role of Other Constituencies, July 1997 (erschienen in: Pezard, Alice;Thiveaud, Jean-Marie (Hrsg.): Corporate Governance: Cross Border Experience, Paris, 1997, S. 61-74)

No. 2: Ralf Ewert/Christian Ernst, Strategic Management Accounting, Coordination and Long-term Cost Structure, July 1997 (erschienen unter dem Titel "Target Costing, Coordination and Strategic Cost Management" in Euopean Accounting Review, Vol.8, No.1 (1999), S. 23-49)

No. 1: Jan P. Krahnen/Christian Rieck/Erik Theissen, Insider Trading and Portfolio Structure in Experimental Asset Markets with a Long Lived Asset, July 1997 (erschienen in European Journal of Finance, Vol. 5, Nr. 1, March 1999, S. 2950) 


\section{Kontaktadresse für Bestellungen:}

Professor Dr. Reinhard H. Schmidt

Wilhelm Merton Professur für

Internationales Bank- und Finanzwesen

Mertonstr. 17

Postfach 111932 / HPF66

D-60054 Frankfurt/Main

Tel.: +49-69-798-28269

Fax: +49-69-798-28272

e-mail: rschmidt@wiwi.uni-frankfurt.de

http://www.finance.uni-frankfurt.de/schmidt/WPs/wp/wpliste.html

Mit freundlicher Unterstützung der Unternehmen der Sparkassen-Finanzgruppe Hessen-Thüringen. 